Historic, Archive Document

Do not assume content reflects current scientific knowledge, policies, or practices. 
1. 


\section{POULTRY SUPPLIES.}



ORIT AND BONG MATB Mica Crystal Grit.

\section{IT IS GOOD FOR \\ POULTRY, PIGEONS, CHICKENS, GEESE, TURKEYS AND BIRDS.}

Everyone knows that hens have no teeth and that the food is masticated in the gizzard. The gizzard itself is a feeble agent, and cannot perform its functions without the aid of some substance that is hard and sharp. Nature prompts the hen to pick up the swallow gravel, glass, smail shells and other substances, but it may be noticed that they prefer such as are sharp and irregular: and the gizzard is not injured, no matter if the sharpest and keenest glass be swaliowed.

Common sense, therefore, teaches us, and all authorities on poultry unite in saying, that grit or shell is absolutely essential to the good health and egg producing qualities of the fowl.

\section{For the Young Chickens}

Feed nothing for twenty-four hours after the chick is hatched, excepting MICA CRYSTAL GRIT (Chick Size.)

And after you begin feeding the regular food, keep a small pan or box of the grit. frequently replenishing, where they can have easy access to it. It will prevent muc $\mathrm{h}$ of the looseness of the bowels (bowel disease) which is so fatal and which is largely caused by indigestion, from undigested food in the gizzard and crop. Give them plenty of chick size and they will be strong and healthy, will grow up to be a credit to the farm, and a source of profit to the owner. Mica Crystal Grit has given the highest satisfaction to all who have used it, and we recommend it to all poultry raisers as being as necessary as food itself. Send us a trial order, and you will never be without MICA CRYSTAL GRIT. We sell two sizes, viz: Poultry size, 5-lb. bag 12c., $10 \mathrm{lbs}$. 20c., $25 \mathrm{lbs} .40 \mathrm{c} ., 100 \mathrm{lbs}$. $\$ 1.00$. Pigeon and Chick size, each, 5.lb. bag 15c., $10 \mathrm{lbs}$. 25c., 25 lbs. $50 \mathrm{c}$, $100 \mathrm{lbs}$. $\$ 1.25$.

\section{Tleat Meal}

This is prepared with great care, and is shipped by us to all parts of the United States, principally to parties who are engaged in raising poultry and eggs for market. It is the finest thing we know of to make hens lay during the winter. High prices always prevail at this season of the year, which makes it extremely profitable to feed. 5 lbs. 20 c., 10 lbs. $35 \mathrm{c} ., 50$ lbs. $\$ 1.50$, $100 \mathrm{lbs}$. $\$ 2.50$.

\section{Crushed Oyster Shell.}

This is a most important article for the poultry yard through the winter, and should be liberally supplied to the fowls. When everything is frozen or covered with snow, they must be helped out if eggs are wanted, 5 lbs. $12 \mathrm{c}$., 10 lbs. $20 \mathrm{c}$., $25-1 \mathrm{~b}$ bag $40 \mathrm{c}$, $100 \mathrm{lbs}$. $\$ 1.00$.

\section{Granulated Bone.}

Is about the size of wheat, and can be fed like any other food in grain, about one handful for every five fowls daily, or every other day. In either manner it furnishes a valuable food for poultry at all seasons of the year. 5 lbs. 20c., 10 lbs. 35c., 100 lbs. 82.

\section{Bone Meal.}

For mixing once a day with soft feed this is unsurpassed. Laying hens and young chickens whose digestive powers are not strong are much benefited by this, especially during the winter months, or where closely confined in yards. This is the same as the "Granulated Bone" described above, only it is ground much finer. 5 lbs. $25 \mathrm{c}$., 100 lbs., $\$ 2.50$.

\section{Sure Death to Lice.}

This is in the form of a very fine tobacco powder and should be thoroughly dusted in the nests. "wallows," poultry houses and coops. 1 ib. 5 c., 5 lbs. 20 c.

\section{Canada Field Pea.}

A very small round pea, which pigeons are fond of and can swallow readily. Qt. $10 \mathrm{c}$., bushel, $\$ 1.00$.

\section{Sunflower.}

Used largely for feeding birds and pigeons. Lb. 15c, 2 lbs. $25 \mathrm{c}$. 


\section{Improved Little Giant Duster.}

Dusts Potato Vines as fast as you walk, two rows at

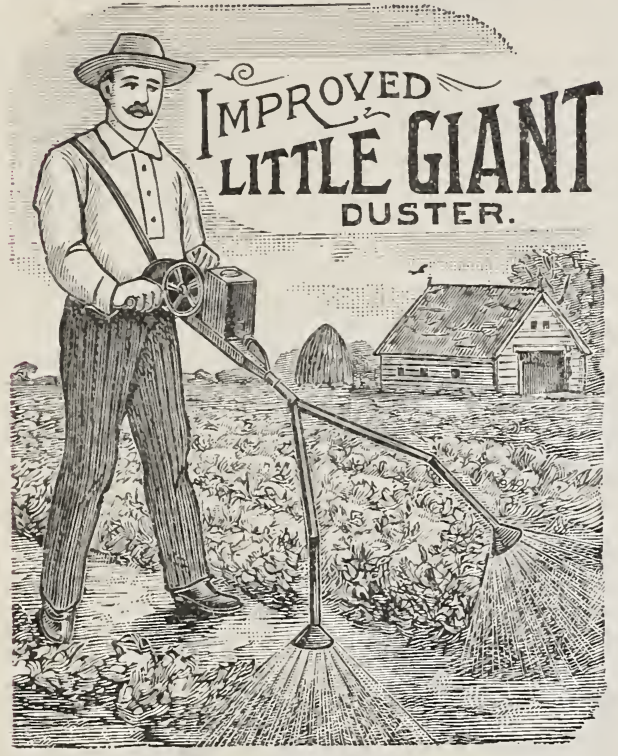

...DIRECTIONS...

Keep the working parts well oiled. $\mathrm{Be}=$ fore filling the reservoir, see that the gauge connected with the thumbscrew is closed. and kept closed when not in use. To distribute clear Paris Green or Purple, open slide about the thickness of a slieet of note paper. The quantity discharged should hardly be perceptible. When mixed with flour, lime, etc., about 1-16 to $1 / 8 \mathrm{inch}$. If the powder drops into the barrel faster than discharged, the slide is open too far. The material must not be damp, but a dry powder. The gauge sliows how far the slots are open, without looking inside.

Any material likely to contain hard lumps slould first be sifted. Flour is free from lumps and sticks best to foliage.

For dusting two rows of Potatoes at once, attach "Y" or No. 2 nozzle, then to each branch a tube and a No 1 nozzle and the spreaders if desired. By turning the No. 1 nozzle, rows of any width may be covered.

When the gun is held in an upright position, as in orchard use, keep reservoir well filled and open gauge $1-16$ to $1 / 8$ inch.

The nozzle may be turned in any direction so as to blow the powder down, or up under the leaves, or sidewise, as desired.

DISTRIRIITES Paris Green, London DISTRIBUTES Purple, Hellebore, Sul= phur, Lime, Dry Bordeaux Mixture, Dry Bordeaux Mixture and Paris Green Com= pound, Spanish Pink, Pyrethrum Powder,

PRICE \$5.00.

Etc.

THIS MACHINE KEEPS THE POISON AT A SAFE DISTANCE FROM THE OPERATOR.

\section{A SELF-OPERATING OR AUTOMATIC SPRRAYER,}

\section{WHAT THE "AUTO-SPRAY" WILL DO.} tinuous spray for nine minutes-This means that the "AUTO-SPRAY" can be charged in fifteen seconds, when it will work uninterruptedly long enough to spray a quarter-acre of potatoes.

\section{AS $A$}

MONEY SAVER.

The "Auto=Spray" leads a11 modern spraying improvements. Less than a week's use will more than save the cost of a sprayer, figuring a man's time at $\$ 1.00$ per day, to say nothing of the saring in material. When in use the "Auto-Spray" is perfectly air and water tight, so that there is no slopping or waste and entirely does away with the horror of expecting at any time to get a splash in the face with some poisonous mixture as is the case in using the old style sprayers.

\section{...DIRECTIONS...}

The above cut shows the air chamber and reservoir combined. Fill the reservoir not more than two-thirds full with the solution ready forspraying, insert the air pump at the end of the can, and all is ready for the operation. The sprayer being carried by the shoulder strap leaves both hands of the person operating nothing to do but direct the spray. The spray can be made to flow faster or slower by merely turning the cock of the spraying nozzle, and will throw either a cloud-like shower or a solid stream

\section{FRUIT CROPS DOUBLED}

and in many cases increased five fold by spraying is shown by tests at Goverment Experimental Station, and by individual orchardmen.

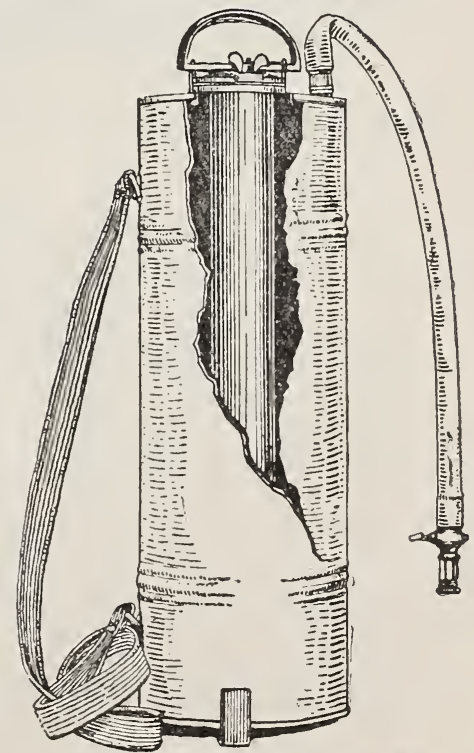

AUTOMATIC SPRAYER.

Made with Solid Copper Reservoir. PRICE, \$6. 50 . 


\title{
Beans.
}

\section{Dwarf or Bush.}

\author{
German, Bohnen. French, Haricot.
}

CULTURE.-One quart to 100 feet in drills, or 150 hills; one bushel per acre. A succession of sow* ings can be madefrom the first week in May until September. These dates are for the latitude of Michigan, further south the sowing must be done earlier, further north later. Plant in drills about two inches deep, and from 18 inches to two feet a part, according to the richness of the soil; the poorer the soil the closer they can be planted. The seeds should be dropped about two inches apart.

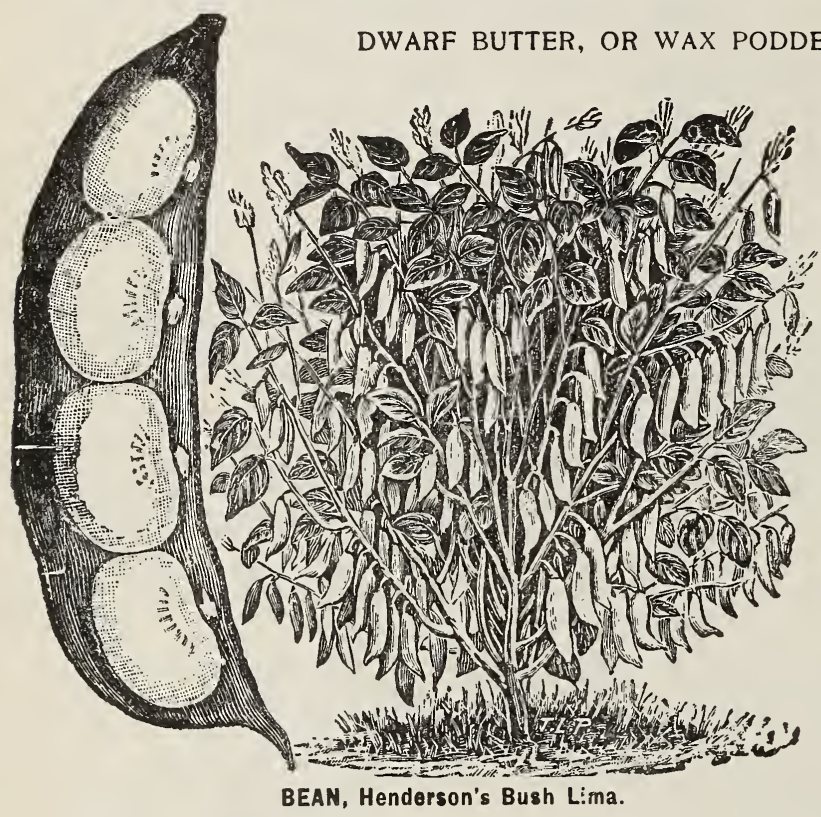

Golden Wax. Very popular; round pods; a well-known standard sort. One of the most delicate and finely fla. vored as well as earliest of the wax sorts. Best for mar. ket or home garden.

Prolific German Wax. An improved strain of Black Wax. of more vigorous habit and far more productive. Pods waxy yellow, with slighitly curled point.

Wardwell's Kidney Wax. Purely wax pods, long, flat. and remarkably free from rust.

Improved Rust=proof Gulden Wax. An improved strain of GoldenWax with smaller pods

Challenge Dwarf Black Wax. An extra early strain of the dwarf Black Wax.

Scarlet Flageolet Wax. Flat, stringless pods of great length and breadth; very productive.

\section{GREEN PODDED VARIETIES.}

Early Red Valentine, Improved Round Pod. For snaps there is nothing superior to this variety among the green podded sorts. Our strain of this popular and excellent variety is a great improvement on the Early Red Valentine. which we have long ago discarded. It is much earlier and is one of the most profitable sorts for private use or market.

Refugee, or Thousand to One. Medium to late; very productive and tender, and largely grown for main crop; round pod.

Early Kidney, Six Weeks. Early; the leading market sort ; full, flat, green pods.

Royal Dwarf Kidney. Excellent either for shelling when green, or baking when ripe.

Large White Marrow. Excellent for either shelling when green, or baking when ripe.

Early Marrow Pea, or Dwarf White Navy. Excellent either for sheiling when greed or baking when ripe. 


\title{
Beans, Dwarf or Bush Lima.
}

Henderson's Bush Lima Bean. We place this first among the bush lima beans advisedly, because we are convinced that for the latitude of Michigan it is the most practicable variety to plant, especially by those who depend upon selling the crops. It is at least two to three weeks earlier than the bush forms of the large lima, and never fails to y eld a good crop before killing frosts. Moreover, its earliness brings it on the market so long before the large limas that handsome prices may be realized for it.

Burpee's Bush Lima Bean. A bush form of the true Large Lima. The plants are uniformly dwarf, but enormously productive, single plants under favorable circumstances yielding from 150 to 350 pods. The pods are as large as those of the Large Lima, and contain from four to six very large flat beans of the best quality. While not quite as early as Henderson's Bush Lima, this is incomparably better in quality, fully equaling in this respect the Large White Lima. Any one who has tried this variety will bo desirous of planting it again.

\section{Beans, Pole or Running.}

\author{
German, Stangennen French, Haricot a Rames.
}

CULTURE.-One quart to 150 hills, one-half bushel per acre. These are more tender, and require rather more care in culture than the Bush Beans, and should be sown two weeks later. They succeed best in sandy loam, which should be liberally enriched with short manure in the hills, which are formed, according to variety, from three to four feet apart. From four to five seeds are planted n each hill, about two inches deep. As the matured bean is used mostly, the season is .oo short for succession crops in the north, though it is advantageous to plant succession crops in the southern states, where ihe season of growth is often from March to November. Rough cedar or similar poles about seven or eight feet long should be used for Lima Beans to climb on. They should be set in the ground at least 18 inches, so as to prevent being blown over.

Early Jersey Lima. Ten days earlier in maturing than the large Lima. The best sort for market or private use ; the best of all.

Large White Lima. Largely grown and highly esteemed.

King of the Garden Lima. Large in pod and bean.

Seibert's Early Lima. In earliness, ease of shelling, size, beauty and quality of the green beans, this new variety is far in advance of all other sorts, and must come to be recognized as the best of all for either the garden or market.

Red Speckled Cut Short, or Corn Hill. An old variety, very popular for planting among corn, and it will give a good crop without the use of poles; vines medium, not twining tightly, with dark coiored, smooth leaves and white blossoms in small clusters ; pods short, cylindrical and tender ; beans nearly oblong, cut off diagonally at the ends, white, covered at one end and partially over the whole surface with reddish brown dots.

Kentucky Wonder or Old Homestead. This variety is ten days earlier than any other green pod pole bean, very productive and stringless.

London Horticultural or Speckled Cranberry. Showy and excellent, either as a snap or shell bean.

Dutch Case-Knife. Pods long, green and flat; can be either snapped or shelled.

Scarlet Runner. A popular English variety; very ornamental, with scarlet blossoms.

White Runner. Similar to the scarlet, but has white blossoms. 


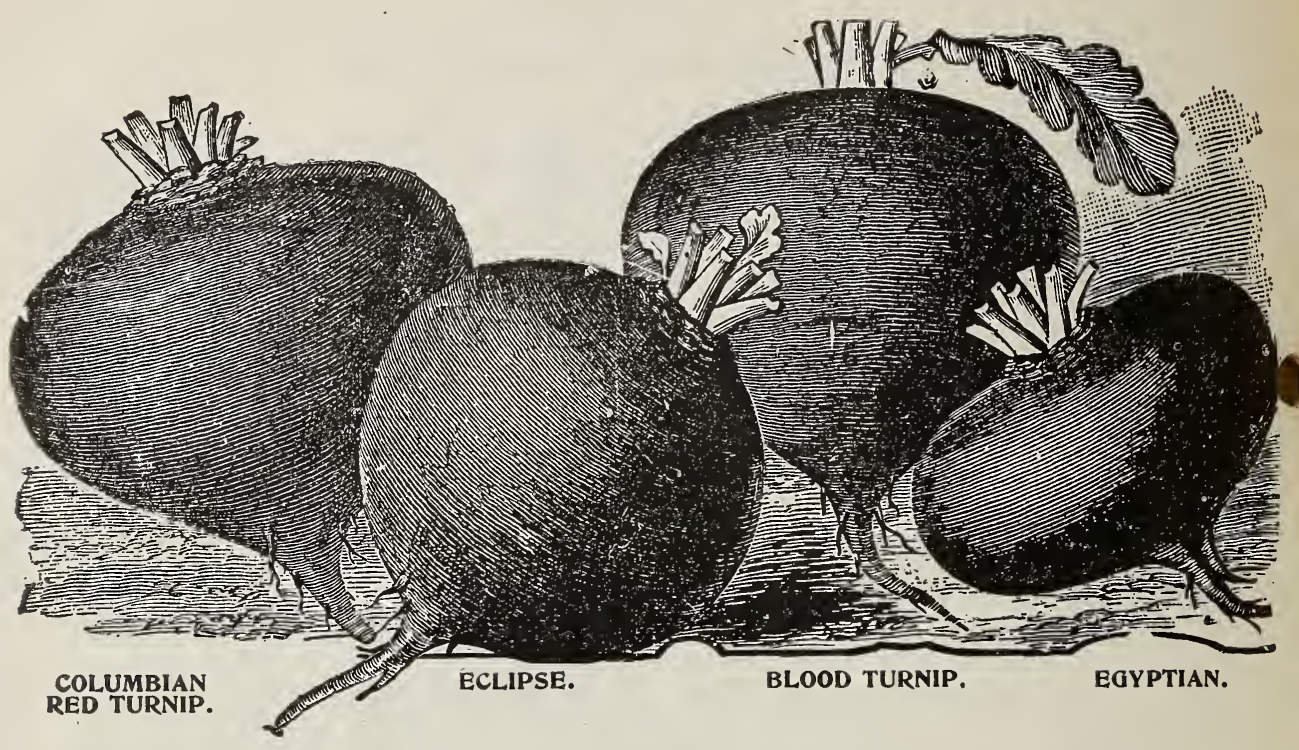

\section{Beet.}

German, Runfelrübe. French, Betterave.

Culture. One ounce to $50 \mathrm{feet}$ of drill, six pounds per acre. The soil which is best suited is that which is rather light and thoroughly enriched with manure. For an early supply, sow in spring as soon as the ground becomes fit to work, in drills about one foot apart and two inches deep. For main crop, sow the first week in May, and for winter use sow in June.

Extra Early Egyptian. Very early and of dark blood color. rather flat in shape.

Early Eclipse. Very early; tops small, dark purplish green shading to lighter color on outside of the leaves. Roots nearly globular, with a small tap root and very small collar. Flesh dark red, zoned with a lighter red, very sweet, crisp and tender, especially when young, One of the most desirable sorts for bunching.

Crosby's Egyptian, Select Strain. Far superior to the ordinary stock; is earlier, has larger root and keeps longer.

Columbian Red Turnip. One of the best strains of beets for the gardener as well as for the home garden; fine shaped bulbs, small neck and short tops; color deep "ed.

Eariy Blood Turnip. Dark red and of fine flavor; productive, good winter keeper.

Dewing's Early Turnip. Of fine form and flavor, and good for market.

Turnip Bassano. A very early light-colored turnip beet.

Detroit Dark Red Turnip. Leaf-stems and veins dark red, blade green ; roots globular or ovoid ; peculiarly smooth ; color of skin dark blood-red, flesh bright red, tender and sweet, and remaining so for a long time.

Half=Long Blood. An excellent half-long, second early; good also for winter use.

Long Dark Blood. Long, smooth and very dark red; a late variety. Our strain of this variety cannot be excelled.

Swiss Chard, Silver or Sea Kale Beet. Grown exclusively for its leaves. The middle of the leaf can be used and served like asparagus, the rest of the leaf like spinach. 


\title{
Mangel Wurzel Beet.
}

CULTURE.-Six to eight pounds of seeds will sow one acre. The following varieties are extensively grown for feeding stock, and are excellent food to increase the flow of milk. As they grow much large than the varieties cultivated for table use, they require more room, and should be sown in drills about two feet apart. The seeds should be dropped about two inches apart in the drills, and when strong enough, thin out to twelve or fifteen inches in the row. The long varieties are best suited to deep soil, and the globe sorts succeed better than the long sorts on sandy soil.

Mammoth Long Red Mangel Wurzel. The most largely grown of any of the Mangels; roots attain an enormous size, producing 30 to 50 tons to the acre; quality superior; the best for deep soil.

Golden Tankard Mangel Wurzel. Best and most popular for dairy farming; a very large, yellow-fleshed sort; it contains a large amount of sugar; fine for either cattle or sheep; grows largely above ground, is hardy and a heavy cropper.

Yellow Ovid, or Intermediate Mangel Wurzel. An excellent sort for stock; yellow-fleshed; very productive, and is sweet and finegrained; fine keeper.

Orange Globe Mangel Wurzel. This is the best Yellow Globe in cultivation; heavy yielder and-splendid keeper. We highly recommend this strain.

Red Globe Mangel Wurzel. Globe-shaped, red, similar to Yellow Globe; good sort for stock; preferred by many.

French White Sugar, Red Top. Grows to a large size, and is useful for making sugar, as well as for stock feeding.

Vilmorin's Improved Imperial Sugar. A much improved strain of the preceding; very valuable as a sugar producing beet.

Lane's Imperial Sugar. A white-fleshed, handsome and very pro. ductive strain; harder than French White Sugar; this sort contains a large percentage of sugar.

French Yellow Sugar. Yellow-fleshed, otherwise similar to French White Sugar Beet and used for same purpose.

\section{Cabbage.}

\author{
German, fopflohl. French, Chou Pomme.
}

CULTURE.-One ounce will produce 1,500 plants. The requisites for complete success are: First, good seed. Second, rich, well-prepared ground. Third, frequent and thorough cultivation. A heavy, moist and rich loam is most suitable, which should be highly manured and worked deep. The early sorts should be sown very early in hot-beds, hardened off by gradually exposing them to night air, and transplanted to open ground, setting eighteen to twenty inches apart as early as possible in the spring. The late autum and winter varieties may be sown from the middle to the last of spring, and transplanted when about six inches high, one and one-half to three feet apart in the row, owing to the size of the

variety. Shade and water the late sowings in dry weather to get them up. It is important that the plants should stand thinly in the seed bed, or they will run up weak and slender and be likely to make plants should

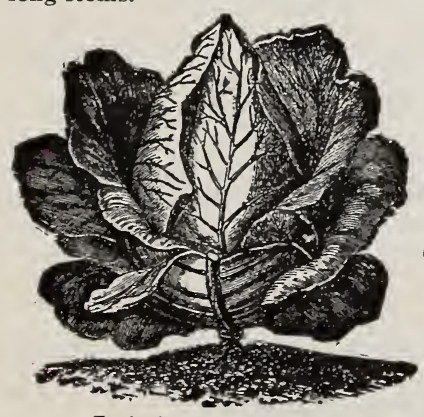

Early Jersey Wakefield.

FIRST EARLY SORTS.

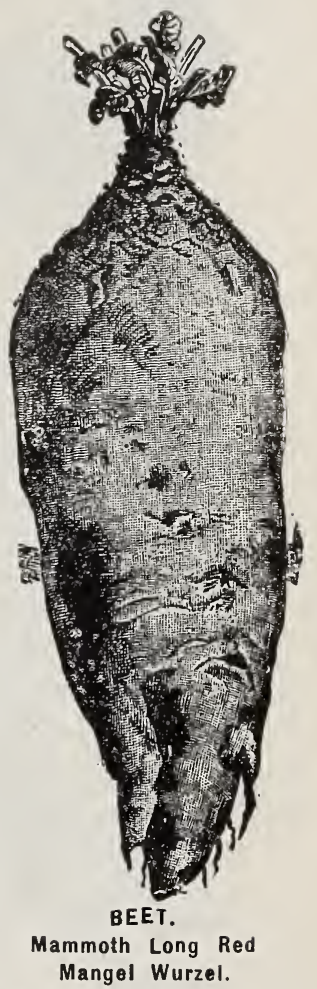

Mammoth Long Red

Early Jersey WakefieId. The leading early variety, pointed heads; fine for early market.

Charleston, or Large Wakefield. Popular with market gardnerers in the South.

\section{SECOND EARLY SORTS.}

The Lohrman Seed Co's Earliest Round Head. It is fully one-third larger than any other early summer cabbage. Detroit gardeners can riot afford to plant any other kind for early market.

Henderson's Early Summer. Heads large, round and very compact; ten days later than Jersey Wakefield; and of the earliest large heading varieties.

Early Winningstadt. One of the best for either early or late use; it rarely fails to form good, solid heads even where other varieties fail entirely; heads cone-shaped and a good keeper. 


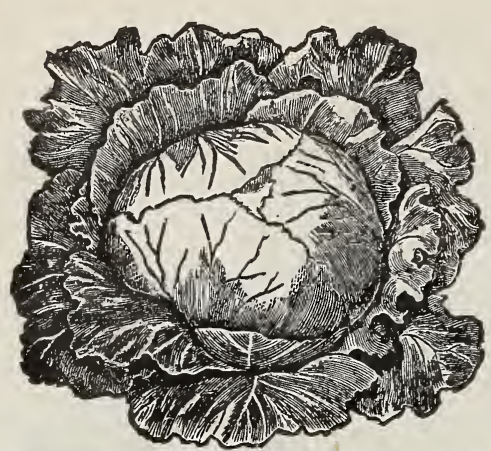

The Lohrman Seed Co.'s Earliest Round Head.

Burpee's All Head Early. The largest heading of the second early sorts.

(Fottler's Early Drumhead, br Brunswick Short Stem. An early drumhead of large size, follow. ing closely the Jersey Wakefield and other very early sorts.

Gregory's Deep Head. Probably the best second early cabbage. Fully as early as Fottler's Brunswick, and makes a deeper, solider head. While largely used for early crops it is fully as much grown by our market gardeners for general and late planting. The plants are medium size and form large, deep, very solid, long-keeping heads of excellent quality. Our stock is especially fine and will be sure to please all who use it.

All Seasons (Vandergaw). An early Drumhead cabbage, yielding heads of good size. Very desirable either for early or fall use.

Henderson's Succession. One of the best of cabbages; heads very large and somewhat flat; ten days later than early summer; much prized by gardeners.

\section{LATE, OR AUTUMN AND WINTER SORTS.}

Premium Late Flat Dutch. This standard late cabbage cannot be excelled for autumn and winter use where a large, solid, long-keeping variety is wanted. We have taken great pains to have the seed we offer pure and from stock of unrivalled excellence.

Henderson's Autumn King. Well named; for it is the king of autumn, its large, perfectly formed heads making it sell at sight; a splendid keeper.

Premium Late Drumhead. Heads large, flat and solid, and a good keeper; planted for main crop for winter keeping.

Mammoth Rock Red. The largest and surest head. ing red cabbage; heads as large and solid as Flat Dutch and fine-grained.

Savoy, Improved American. This is the best of

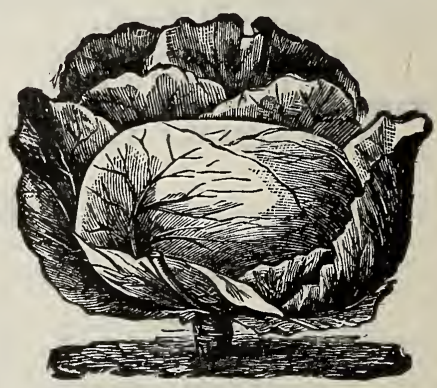

Premium Late Flat Dutch, the Savoys for market or family use; heads large with crisp, wrinkled leaves.

Hollander. Heads medium size, round and very solid; being the hardest heading cabbage known. Matures quite late, and is the best sort to keep over winter. The weight of a trimmed head is fully one-half more than of any other variety of a similar size.

\section{Cauliflower.}

CULTURE,-One ounce will sow a bed of 40 square feet, and produce 2,000 plants. The cultivation is similar to that of cabbage. For early fall crops, sow in March and transplant in June, in rows four feet apart, setting the plants two feet apart in the row; water frequently if the ground be dry. Frequent hoeing, and a liberal supply of rich liquid manure, to keep up a continuous and rapid growth, will produce splendid heads of a most delicate flavor. It facilitates blanching if the leaves are gathered loosely together, and tied over the top of the head to protect from the sun. Sow as late as June 20 for late crops, in beds or in drills, covering one-half inch deep.

Henderson's Early Snowball. This is undoubtedly the finest variety ever introduced; it is the earliest and produces beautiful snow-white heads of the most delicious flavor. The seed we offer is pure and genuine, and sure to prove satisfactory.

Extra Early Dwarf Erfurt. The finest strain of the Erfurt Cauliflower.

Early Erfurt. A leading standard variety of excellent quality.

Large Late Algiers. A sure heading lata rariety. 


\title{
Carrot.
}

\author{
German, Möhre. French, Carotte.
}

Colture,-One ounce will sow 100 feet of drill; three pounds per acre. Carrots require a very finely pulverized soil to grow them to perfection. A good, light and well-enriched sandy loam is the best for this crop. For field culture, sow in drills three to three and one-half feet apart, so as to cultivate by horse. Market-gardeners sow in drills about 18 inches a part, and cultivate by hand. For early crops cover one-half inch deep, and thin to six inches apart in the rows; for late, cover three-quarter inch deep, and thin to four inches.

Early Scarlet Horn. Excellent for forcing or early out door planting; orange in color; blunt root; four inches in length.

Guerande, or Ox Heart. Roots short and very thick, and intermediate between Scarlet Horn and Chante. nay; color deep orange; fine grained and sweet; easily dug; annually grows in favor.

Chantenay,Stump Rooted. A stump. rooted variety, somewhat resembling the well-known Nantes Carrot, but having a larger shoulder and being much more productive.

Early Half Long Scarlet, Stump Rooted. In size and time of matur. ity it is between the Early Scarlet Horn and the Long Orange.

Danvers, Half Long. One of the heaviest croppers; roots dark orange color, eight to ten inches in length, thick, and ending in a somewhat abrupt point; first-class for all soils.

Long Orange Improved. One of the most desirable for either field or gar. den culture. It grows to a large size, fair specimens averaging twelve inches in length. and three inches diameter at the top. All who have cattle should raise a surplus of this carrot for feeding milk cows during winter. It increases the flow of milk and imparts to the butter a delicious flavor and a rich golden color.

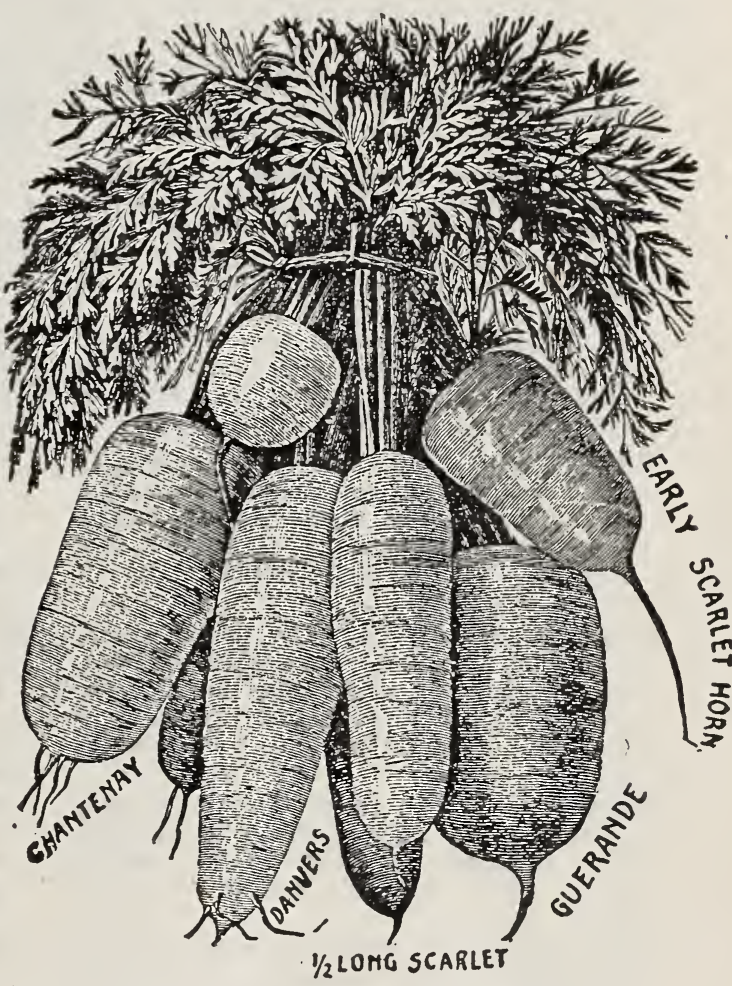

Improved Short White. New, for stock feed; the best white carrot, and furnishes the largest yield at the least expense.

Large White Belgian. Roots very large and smooth; grown exclusively for stock feeding.

\section{Root Crops for Feeding Cattle.}

\section{Carrot, Sugar Beet, Mangel Wurzel, Turnip and Ruta Baga.}

\footnotetext{
It is surprising how little attention has been given to their culture in this country, particularly when we take into account our long, dry summers, which diminish the yield of the hay and other fodder crops, as well as our long winter feeding season, in which some succulent food, such as roots, is so useful to feed with hay and other dry provender. Every farmer should have a few acres of agricultural root crops on his farm, and he will find them invaluable in feeding his stock during the winter. Many have the idea that it is impossible, or at least difficult, to protect such crops during the winter, but when it is considered that in Canada they are much more largely grown than in the United States, and that they can be "pitted" with safety even in the most rigorous winter, it will be readily seen that this idea is erroneous.
} 


\section{Celery.}

German, Sellerie. French, Celeri.

CULTURE.-One ounce will produce 7,000 plants, two ounces per acre. Sow seeâs in hot-bed in February or March, or out doors in A pril. As soon as the plants a re about three inches high transplant to a nicely prepared bed in the border, setting them four or five inches apart. When they are eight inches high, and fine, stocky plants, set them in the trenches. Earth up a little during the summ?r, keeping the leaf stocks close together, so that the soil cannot get between them. Finish earthing up in autumn, and never hoe or earth up in moistw eather, nor when the plants are moistened with dew.

To preserve celery for winter, dig treuches one foot in width and deep as the top of the plants. Stand the celery in these, erect, as they grew, with what dirt adheres to the roots, packing closely but not crowding. After the trench is filled it should be covered with straw or leaves as a protection from frost. Do not cover until the weather becomes quite cold and then only a little at a time, as the cold becomes greater. Celery will bear a good deal of f rost. The trench must have good drainage.

Golden Yellow Large Solid, or Golden Self-Blanching. Our strain of this variety is unexcelled and absolutely reliable. This is beyond doubt the best celery for early market use. Plants of a yellowish-green color when young, but as they mature the inner stems and leaves turn a beautiful golden yellow, which adds much to their attractiveness and makes the work of blanching much easier.

White Plume. This variety has great merit as an early market sort, requiring no more labor to blanch it than Golden Yellow Large Solid, yet we do not think that it compares with Golden Yellow either in flavor or solidity.

Perfection Heartwell. The best flavored, most crisp and tender of the white varieties. The stalks are medium size, round, very solid, crisp and tender, and of exceedingly fine and nutty flavor; and a fine winter sort,

Kalamazoo White Solid Dwarf. Grown extensively by celery growers at Kalamazoo, Michigan; a dwarf white variety easily blanched, a good keeper and popular as a shipper.

Golden Heart. Very solid and the heart is of a golden yellow when blanched; excellent keeper, and fine for garden or market.

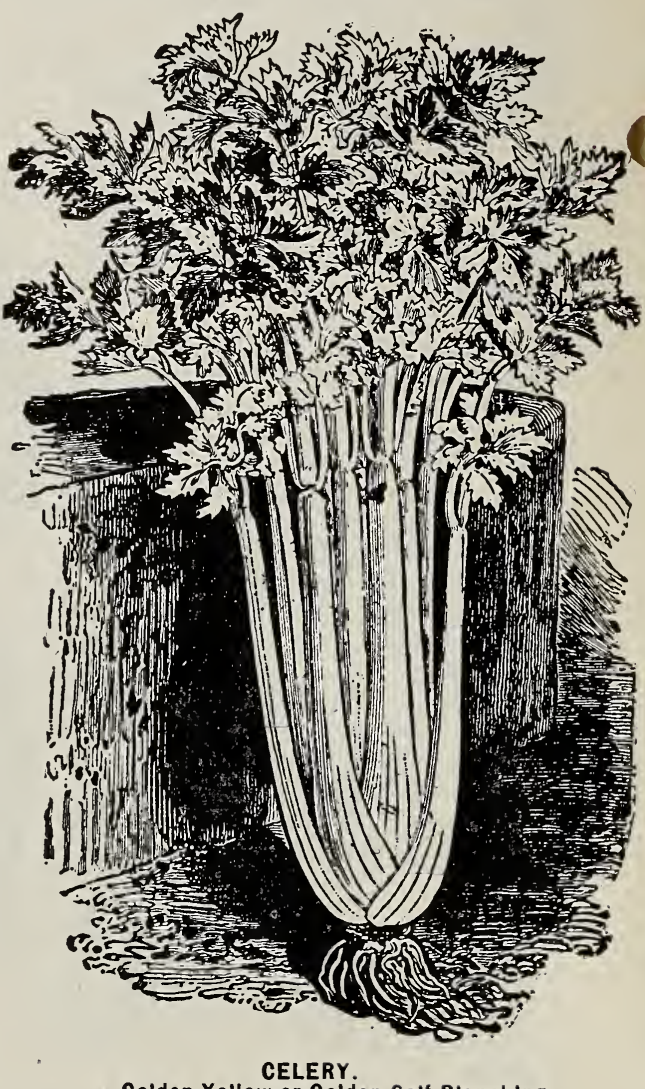

Golden Yellow or Golden Self-Blanching.

\section{Celeriac, or Turnip=Rooted Celery.}

German, Inoll=Sellerie. French, Celeri-rave.

The root of this varlety is turnip-shaped, tender and marrow-like, having a sweeter taste and stronger odor than other varieties. It is used principally for seasoning meats and soups.

Large Smooth Prague. An improved form of turnip-rooted Celery; round, smooth roots with very few side roots. This is the largest variety and one of the very best.

Soup Celery. For flavoring soups, pickles, etc.

\section{Cress.}

German, ̊refie. French, Cresson.

Curied, or Peppergrass. This small salad is much used with lettuce, to which its warm, pungent taste makes a most agreeable addition.

True Water. This is quite distinct from the last, and only thrives when its roots and stems are submerged in water. 


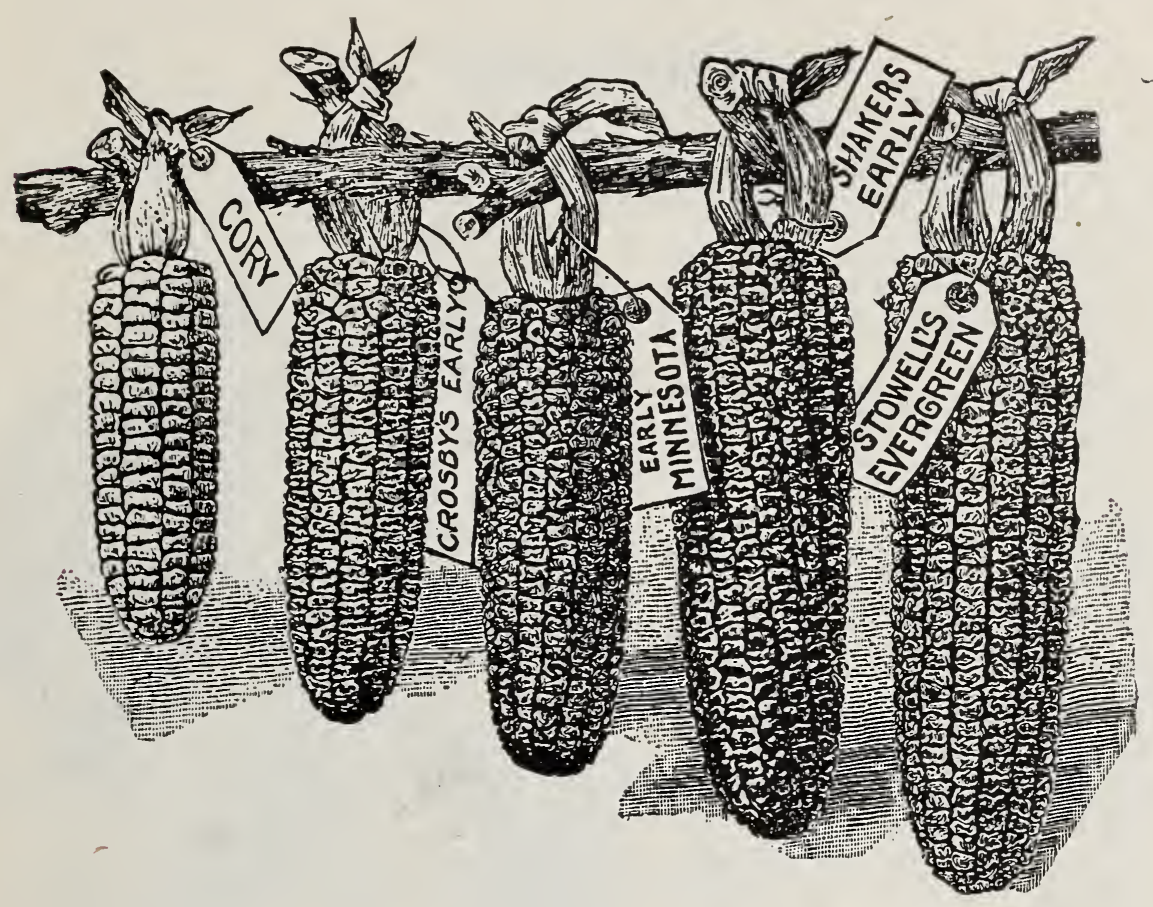

\section{Corn, Sugar.}

German, Weljhtorn. French, Mais.

CUlture.-One quart will plant 200 hills; one peck will plant one acre in hills. Corn requires a good soil and a warm situation. Commence, for first early, by planting the early varieties about May 1 , and if a continuous supply is wanted all summer, make plantings about two weeks apart from May 1 until the last of July, first planting early varieties, then later ones. Plant in rows three feet apart, and make the hills about the same distance apart in the rows. Five kernels in the hill are plenty. Cover about one inch deep for early, and a little deeper for late. Thin to three plants in a hill.

Extra Early Cory. A very early variety, with good sized ears and large grains ; excel. lent for market, and has attained wide popularity.

White Cob Cory. A selection from Red Cory, over which it is a great improvement, being equally as early and having white kernels and white cob.

Crosby's Early. Very early, productive, ears rather short, and of a rich, sugary flavor.

Early Minnesota. Best early sort, not only for market, but for the private garden. Stalks short and not suckering, bearing one or two ears well covered with husks; ears long, eight rowed; kernels very broad, sweet and tender, not shrinking much in drying.

Shaker's Early. Large ears; excellent quality; fine market sort, follows the Minnesota ; much used by canners.

Pee and Kay. A large-eared, fine sort; white grains, tender and sweet.

Hickox Hybrid. Next to Stowell's Evergreen the most popular variety for canning, also prized by market gardeners; earlier than Evergreen.

Old Colony. Ears sixteen to twenty rowed, grain very deep; fit to use a few days earlier than Evergreen.

Black Mexican. Grains black when ripe, but for the table cooks remarkably white. r

Stowell's Evergreen. The standard for quality, and the best known variety; a ite alike with canners and market men; remains a long time in condition for boiling. 


\title{
Cucumber.
}

\author{
German, Bsurfe. French, Concumbre.
}

CUlture.-One ounce will plant 50 hills; two pounds will plant one acre. For earliest use, sow in the hot-bed or greenhouse in February or March, in warm loam, where the temperature is about 90 degrees; cover half an inch deep. and when the plants are of fair size. transplant into hills. Plant for general use in the open ground, about June 1, in hills six feet apart each way, and thin, "to three plants in a hill.

Early Russian. Fruit three to four inches long, thick, oval, pointed at each end, covered with fine small spines.

Early Cluster. Fruit borne in pairs.

Early Short Green or Early Frame. This variety ought to be ranked among the pickling sorts, as it is first-class for this purpose. Our stock is very superior.

Chicago Pickling. The favorite with Chicago pickle manufacturers; fine shape and very productive.

Boston Pickling. Fruit short, smooth and pointed at each end; color bright green and a great yielder; one of the best sorts for pickling.

Early White Spine. Jne of the best sorts for table use. Vines vigorous, fruiting early and abundantly; fruit uniformly straight and handsome, light green with a few white spines; flesh tender and of excellent flavor. In this country this variety is used more than any other for forcing under glass.

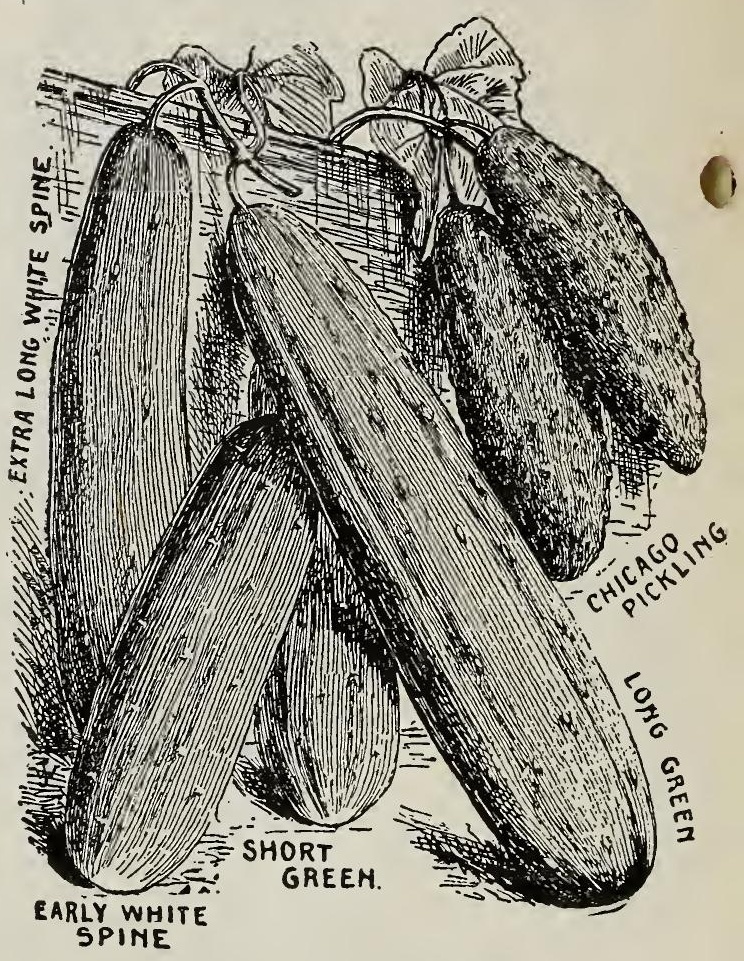

Extra Long White Spine. Largely used for forcing and early outdoor planting.

Evergreen White Spine. It is very slow to ripen even after being fully grown, and remains in an edible condition longer than any other variety; for handsome appearance and quality it is unsurpassed.

Improved Long Green. The standard all-around variety. It makes an excellent fruit for slicing, quality crisp and delicious. The smaller fruits are used for pickling, and the larger ones can be allowed to ripen for preserving.

\section{Corn Salad. \\ Fetticus or Lamb's Lettuce.}

German, Adterjalat, Rammaralat. French, Mache, Salade de ble.

CULTURE.-Sow the seeds one-half inch deep in drills about one foot apart, during August and September. If the soil is dry, it should be firmly pressed over the seed in order to secure prompt germination. On the approach of severe cold weather, cover with straw or coarse litter. The plants will also do well if sown very early in the spring.

Large Seeded, Large Leaved. This small salad is used during the winter and spring months as a substitute for lettuce and is also cooked and used like spinage. In warm weather the plants will mature in four to six weeks. 


\title{
Figg Plant.
}

\section{German, Eixxpflanze. French, Aubergine.}

CULTURE.-One ounce for I,ooo plants. The Egg Plant will thrive well in any good garden soil, but will repay good treatment. 'The seeds should be sown in hot bed in March or April, and when about an inch high pot in two-inch pots. Plant out about June $I$, two and one-half feet a part.

Improved Large New York Purple. The leading market variety; of large size, skin deep purple, smooth, free of thorns.

\section{Endive.}

\section{German, Endiuixi. French, Chicoree.}

CULTURE.-Endive may be grown at any season of the year, but is most generally used late in the fall. Sow the seed during June or July, in drills fourteen inches apart, and when well established thin to one foot apart.

Small Green Curled. Is the hardiest variety, with beautiful curled, dark green leaves. Large Green Curled. A large growing variety, outer leaves bright, dark green.

Moss Curled. A variety growing considerably denser and having the leaves much finer cut than the Green Curled.

Ever White Curled. The outer leaves are very light colored, frequently white, so that the plant is very attractive, and always brings the highest price on the market.

Broad Leaved Batavian.

\section{Kale, or Borecole.}

Extra Curled German Dwarf Cireen. Rarely exceeding 18 inches in height, but spreading out under good cultivation to three feet in diameter; leaves beautifully curled and bright green.

Tall Green Curled Scotch. Grows about two feet high, leaves dark green, curled and wrinkled; very hardy, and is improved by a light frost.

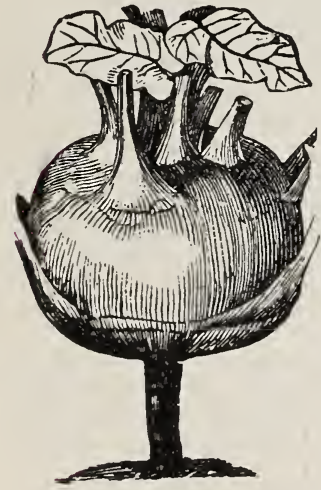

Kohl-Rabi.

Early White Vienna.

\section{Kohl=Rabi,}

\section{Or Turnip=Rooted Cabbage.}

\author{
German, Fahrl-FRatri. French, Chou-Rave.
}

Culture.-One ounce will sow 200 feet of drill; four pounds per acre This vegetable, the popularity of which is increasing, combines the virtues of the turnip and cabbage, but excels both in nutritive, hardy and productive qualities. The seed may be sown in June, in rows 18 inches apart, and the plants thinned out to eight or ten inches in the rows, or start in hot bed in February and March.

Early White Vienna. Short Leaf, extra for forcing: Best for general table use; flesh tender and white.

Large Green. Good for table use and is also good for feeding stock.

Purple Vienna. A little later than white; color bluish-purple.

\section{Leek.}

German, bauxth. French, Poireau.

CULTURE.-One ounce will plant 200 feet of drill; four pounds per acre. The Leek is very hardy and easily cultivated; it succeeds best in a light but well-enriched soil. Sow as early in spring as practicable, in drills one inch deep and one foot apart. When six or eight inches high they may be transplanted in rows ten inches a part each way, as deep as possible. that the neck being covered, may be blanched.

London Flag. The oldest and best known and most largely grown variety.

Large Rouen. Very hardy and strong; shorter, and having very broad, flag like leaves. 


\title{
Lettuce.
}

\author{
German, battich. French, Laitue.
}

CULTURE.-One ounce will sow 120 feet of drill; three pounds per acre. Requires a rich, moist soil and to be crisp and tender needs to be grown in cool weather For winter use sow in hot-beds every two weeks, at the rate of one ounce of seed to four sashes (a sash is three feet long by six feet wide); cover very lightly, and transplant first to three inches apart each way, afterwards to eight inches. For garden or field, sow in rows, and cover one-fourth of an 1 nch deep, and thin out to 12 inches apart in the rows.

\section{EARLY CURLED VARIETIES.}

Detroit Market Gardener's, or Engel's Forcing. The valuable features of this lettuce are: Earliness and Enormous Size, cuttings being made time and again in six weeks after sowing the seed. Long Standing Qualities; by this we mean that it remains longer fresh and unwilted after being cut, than any other lettuce. You cannot afford to sow any other variety for forcing or early outdoor planting.

Grand Rapids. A distinctively forcing and shipping lettuce, beautiful in appearance.

Simpson Early curled. A leading early sort, good for forcing or open ground.

Early Curled Silesia. Early and tender;

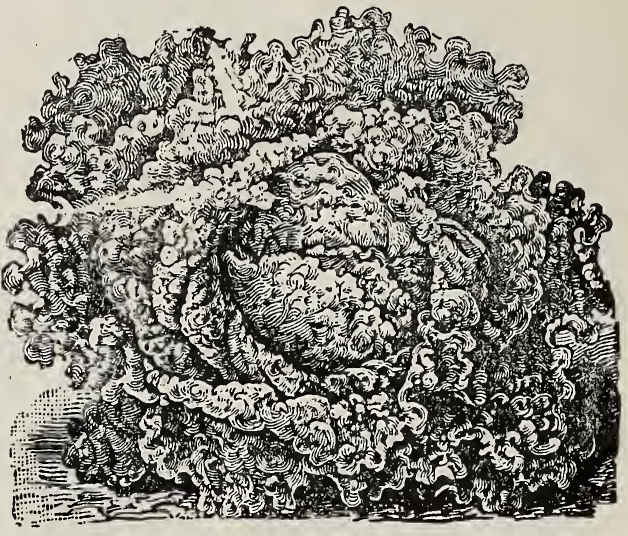

LETTUCE, Detroit Market Gardener's. leaves yellowish-green; good either for the home or market garden.

Black Seeded Simpson. Nearly double the size of Early Curled Simpson; leaves delicate golden yellow; a superior variety either for forcing or sowing out of doors.

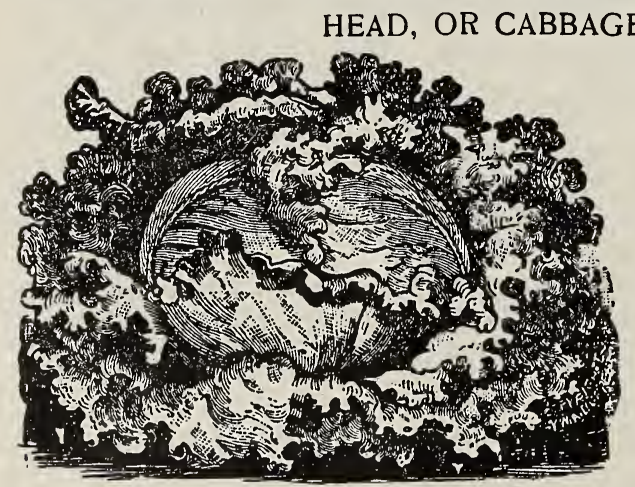

LETTUCE. Hanson.

Hanson. Extensively grown by market gardeners, as it is always sure to make large, handsome heads of excellent quality; outer leaves green with light veins, inner leaves white.

Philadelphia Butter. Leaves thick and nearly round, forming very solid, round heads, which stand a long time before seeding; inner leaves rich yellow.

Frankfort Head, or Salamander. Fine compact heads, which resist summer heat admirably; very popular in some sections.

Satisfactlon Black Seeted. Forms fine large heads of handsome light-green leaves, that are crisp and tender.

Early Prize Head. Leaves green and red, very thin, crisp and tender; one of the very best for private use.

Buttercup. For forcing or out door use; yellow, solid, medium-sized heads; distinct and attractive.

Deacon. A large, solid, cabbage lettuce for summer. We recommend this variety as superior and one of the very best.

Mammoth Black Seeded Butter. Forms very solid, large, round heads, which stand a long time before seeding, inner leaves rich yellow. 


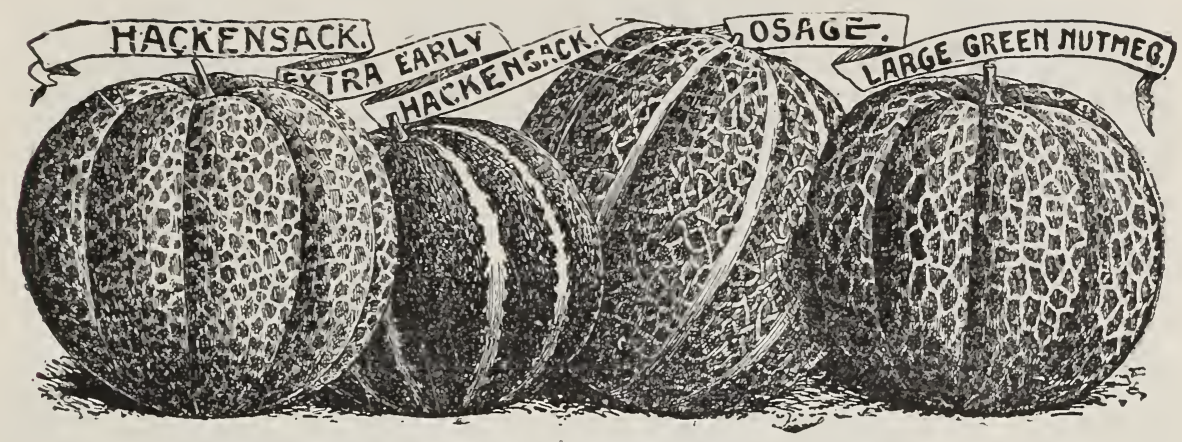

\title{
Melon, Musk.
}

\author{
German, æmelane. French, Melon.
}

Culture.-One ounce will plant eighty hills; two pounds per acre. A rich, deep, sandy loam, well worked and highly manured with old rotton compost, is of the first importance. Plant, when all danger of frost is over, in hills five to six feet apart each way; scalter a dozen seeds to a hill, and after they are out of danger from bugs, thin to three or four plants. When they have four or five rough leaves, pinch off the end of the main shoot, which will cause the lateral branches to put forth sooner. This will strengthen the growth of the vines, and the fruit will come earlier to maturity.

\section{GREEN-FLESHED VARIETIES,}

Jenny Lind. An extra early, small, green-fleshed melon of very fine flavor; round and flattened at the ends.

Extra Early Hackensack. This is the favorite green fleshed melon in Detroit markets. A selection from and an improvement on the old Hackensack, and similar in shape and appearance; nearly as large and fully ten days earlier. One of the finest for market gardeners; quality perfect.

Hackensack. Fruit large, round and flattened at the ends, deeply ribbed and heavily netted; flesh thick and of very fine flavor. A fine market variety.

Improved Large Green Nutmeg. Vines vigorous, hardy, productive; fruit very large, round, slightly flattened at both end̦s, ribbed, covered with coarse netting; flesh very thick and of the highest flavor.

Small Green Nutmeg. This variety is in universal demand for both home and market use.

Montreal Market. Excellent variety of the largest slze; we have had them weighing over 20 pounds. In shape almost round, flattened at ends, deeply ribbed; skin green and netted. Flesh green, very thick.

Baltimore or Acme. Productive and excellent shipping melon. It is a green-fleshed variety of oblong form.

RED OR SALMON-FLESHED VARIETIES.

Emerald Gem., Distinct, very eariy and prolific; skin ribbed, yet smooth, and of a deep emerald green, with a few lighter-colored stripes. The flesh is thick, of a suffuse salmon color.

Osage. This is the favorite market melon of Chicago and Detroit, and many othe. western markets, and offered on the bills of fare of first-class hotels and restaurants. It is globe or egg shaped, slightly netted, skin dark green and flesh orange-pink, very thick and of a flavor not surpassed by any in cultivation; as a market melon it is superior to any variety that can be named and the most profitable.

Princess. In shape this melon is slightly elongated; skin dark green and densely netted; ribs shallow; flesh deep salmon yellow and not surpassed by any in rich, spicy flavor, and has all the excellent points which go to make a splendid market melon, including size, averaging six to eight pounds. 


\title{
Melon, Water.
}

\author{
German, Waffermelone. French, Melon d'Eau.
}

Culture,-One ounce will plant 50 hills; two pounds per acre. Water melons are cultivated in hilis, which should be six or eight feet apart each way, and composed of light moderately rich soil. The hills should be dug about two feet square, 18 inches deep, and half filled with well rotted manure, which must be thoroughly incorporated with the soil. Plant in May, ten seeds to a hill, and when the plants are well up thin out to three plants. Cultivate until the vines cover the ground, and pinch the ends of the growing shoots to induce early fruiting.

Phinney's Early. A valuable early variety for use in the North, and a sure cropper.

Peerless, or Ice Cream. The best melons for private gardens and for market gardeners who deliver direct to consumers; hardy, productive; fruit medium size, ovai, finely mottled; rind thin; flesh bright scarlet.

Kolb's Gem. Largely grown, particularly in the South, for shipments to Northern markets. As a shipping melon it has hardly an equal. The fruit is nearly round; rind dark green, somewhat marbled with lighter shades. Weight 25 to 50 pounds.

Cuban Queen. One of the very best all-round melons. Good to ship, and for home use not excelled by any in quality.

Gypsie, or Georgia Rattlesnake. An excellent market variety; large, oblong; rind dark mottled and striped; a well-known shipping melon

Dixie. It is the best for shipping. Rind darker than Kolb's Gem and more beautifully striped, and much longer in shape.

The Volga. It is perfectly round in shape, averaging 15 pounds in weight. The skin is light green in color, slightly mottled, thin and very hard. One of the earliest.

Long Light Icing. It is uniformly long, oval in shape, and nearly twice as heavy as the Round lcing.

Hungarian Honey. Fruit large, nearly round, dark green, very indistinctly mottled with lighter shade.

Citron. For Preserving. Fruit round.

\section{Mushroom Spawn.}

German, Champignonbrut. French, Blanc de Champigmon.

CULTURB-Mushrooms may be grown in cellars, under benches of greenhouses, or in sheds, wherever the temperature of 50 degrees can be kept up through the winter. The beds should be made from November to February, according to the time the Mushrooms are wanted, and it requires about two months for them to begin bearing. Secure fresh horse-dung, free from straw and litter, and mix an equal bulk of loam from an old pasture with it. Keep this under cover, taking care to turn it every day to prevent heating until the pile is large enough to make a bed of the required size. Three or four feet wide, eight inches deep, and any length desired, are the proper proportions for a bed; but these may be varied. Prepare the mixture of loam and manure, making the bed in layers, and pounding down each with the back of the spade. Leave this to heat through for a few days, and as soon as the heat subsides to go degrees, make holes in the bed about a foot apart each way, into which put pieces of the spawn two or three inches in diameter; fill up the holes with the compost, and at the expiration of a week or ten days the spawn will have thoroughly diffused itself through the bed. Spread a layer of fresh soil over the heap to the depth of two inches, and cover with three or four inches of hay, straw or litter. Examine the bed often to see that it does not get dry. Take special care, however, when water is given, that it be at a temperature of about roo degrees.

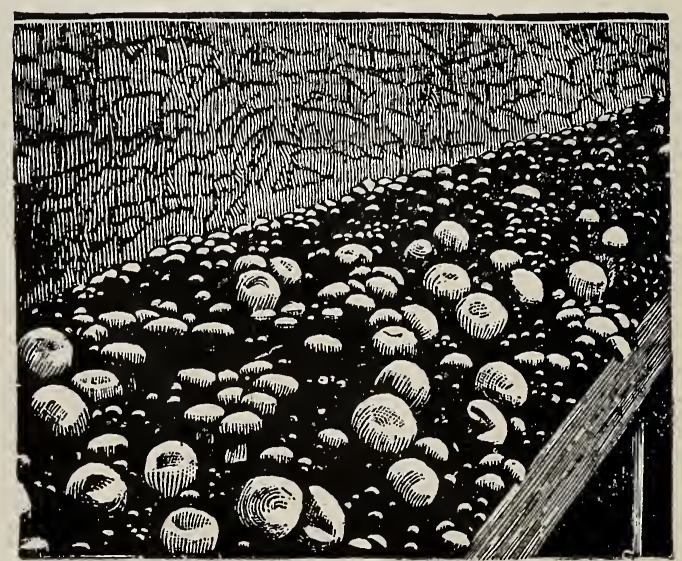




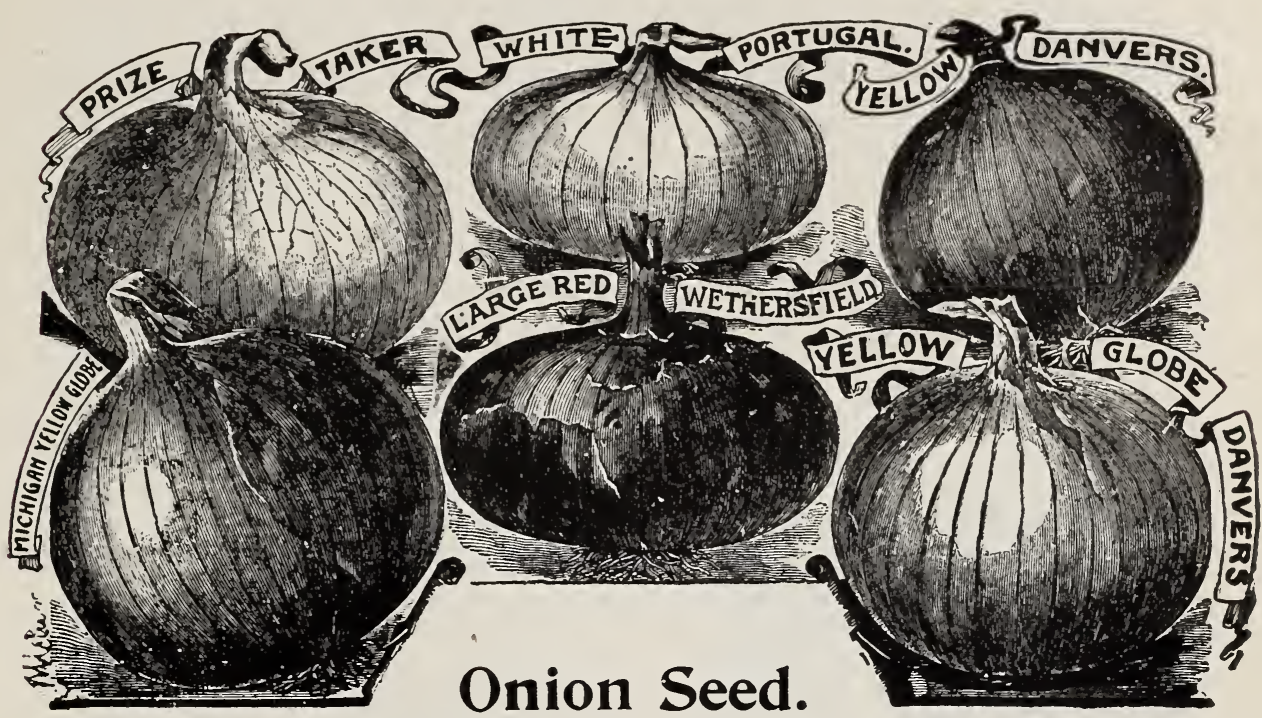

German, 83wiebel. French, Oignon.

CULTURE.-One ounce for 100 feet of drill; five or six pounds in drills for an acre. For sets, 50 to 60 pounds should be sown to the acre, according to the richness of the soil. The onion thrives best in a rather deep, rich, loamy soil, and, unlike most vegetables, succeeds well when cultivated on the same ground for successive years. The best culture requires that the ground should be deeply trenched and manured the previous autumn, and laid up in ridges during the year to pulverize. As early in the spring as the ground is in working order, commence operations by leveling the ground with a rake, and tread it firmly; sow thinly in drills about one-quarter of an inch deep, and one foot a part; cover with fine soil, and press down with the back of a rake or a light roller. When the young plants are strong enough, thin gradually so that they stand three or four inches apart. Keep the surface of the ground open and free from weeds by frequent hoeing, taking care not to stir the soil too deeply, or to collect it about the growing bulbs.

Extra Early Red. Extra Michigan Grown. A very early and abundant yielder; mild flavored, of medium size and a good keeper; bulbs same shape and color as Red Wethersfield, but two weeks earlier.

Southport Red Globe. This variety is of medium size, spherical, with small neck, very deep, rich, red color, and of superior quality.

Large Red Wethersfield. Extra, Michigan Grown. Onion growers who prefer the red varieties will find our Michigan grown seed far surpassing the ordinary Red Wethersfield in size, productiveness and kceping qualities.

Michigan Yellow Globe. Extra Michigan Grown. The largest crops of onions are always produced on rich, black lands. On such soils it is found that a globe-shaped onion gives the largest returns, and to meet the demands of the professional onion growers located on such lands, we have developed this variety. The bulbs are large and uniformly spherical, with very small necks; of a rich orange-yellow color; enormous seed yielders and splendid keepers. No onion grower can afford to plant inferior seed when such as this can be procured.

Yellow Globe Danvers. Extra Michigan Grown. It is immeasurably superior to the average seed offered, not only in shape and color but in productiveness. The product of this seed always finds a ready sale, even when the general crop is a "glut" on the market, and will always average $50 \mathrm{c}$ per bbl. more than any other strain. This, our special strain, is all grown from selected, hand-picked bulbs, none but those perfect in size and shape being set for seed.

Yellow Danvers. A very early sort of great merit; one of the best yellow kinds for markê. 
Yellow Globe Danvers. This is the standard variety everywhere, its uniform shape, bright yellow color and fine quality commending it to all. Yellow Globe Danvers is an excellent keeper and is one of the most desirable sorts for either the professional or amateur gardener.

Large Yellow Dutch or Strasburg. This is the earliest of the large flat yellow sorts. It is a wonderful keeper.

Prizetaker. The color is a bright straw, and it always grows to a uniform shape, which is nearly a perfect globe. Having a small neck, stiff necks are almost unknown. Our seed is the choicest American grown, and not Imported Spanish King, as sold by some dealers.

White Globe. Yields abundantly, producing handsome and uniformly globe-shaped bulbs. The flesh is firm, fine-grained, and of mild flavor. Sometimes called South. port White Globe.

White Portugal, or Silverskin. A large, flat, white onion of mild and pleasant flavor; hard and fine-grained and a good keeper. More extensively sown for sets than any other white variety, and is also largely grown for pickling.

Queen. Particularly valuable for pickles. If sown thickly they will mature perfect, hard onions from one-half to three-quarters of an inch in diameter. A silver-skinned vari

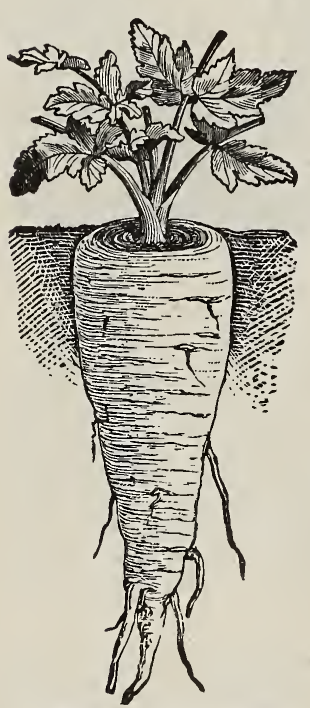

PARSNIP, Hollow Crown. ety, of quick growth and remarkable keeping qualities. If sown in early spring it will produce onions one to two inches in diam. eter early in summer, and if sown in July will, with favorable weather be ready to pull láte in autumn, and be sound and fit for use until the following summer.

\section{Parsnip.}

German, Pastinake. French, Panais.

CULTURE - One ounce per 200 feet of drill; three pounds per acre. Sow as early in the spring as the weather wil, admit, in drills 15 inches apart, covering half an inch deep. When we: up thin out to five or six inches apart in the rows. Unlike carrots they are $1 \mathrm{mproved}$ by frost, and it is usual to take up in fall a certain quantity for winter use, leaving the rest in the ground till spring, to be dug as required.

Hollow Crown, or Guernsey. Roots comparatively short, ending somewhat abruptly with a small tap root; grows mostly below the surface; has a very smooth, clean skin.

Long White Dutch, or Sugar. A standard variety with long, smooth roots.

\section{Parsley.}

German, Petexilix. French, Persil.

CUlture.-One ounce for 150 feet of drill. Parsley succeeds best in rich, mellow soil. As the seed germinates very slowly, it should be sown early in spring, previously soaking the seed for a few hours in tepid water.

Fine Triple Curled. This is a most beautiful and valuable variety.

Champion Moss Curled. Moss-like leaves of a handsome bright.green color; are finely crimped and curled. For garnishing, no variety is more attractive.

Plain, or Single. Plain leaves, excellent flavor.

\section{Pepper.}

German, Pfeffex. French, Piment.

CULTURE.-One ounce wiil produce abont 1500 plants, Sow in hot-beds early in April, and transpln 12 . to the open ground when the weather is favorable.

Red Chili. Red pods two inches long. Very hot.

Long Red Cayenne. The true Cayenne; hot and pungent.

Sweet Mountain. Large, mild; glossy red.

Large Bell, or Bull Nose. The standard sort for market or home use.

Ruby King. Remarkably mild and pleasant to the taste; most excellent for stuffing or for pepper-hash. 


\section{PEAS.}

German, Erbien. French, Pois.

COLTURE.-One quart for 75 feet of drill; two bushels in drills for an acre. Peas come earliest to maturity in light, rich soil. For general crop, a deep loam or a soll strongly inclining to clay is best. For early crops decomposed leaves or leaf mold should be used. For general crops a good dressing shouid be applied; and for the dwarf-growing kinds the soil can hardly be too rich. When grown as a market crop, peas are never staked; for private use they are generally sown in double rows, and the tall varieties stalked up by brush.

Our stock of Peas cannot be excelled either as to earliness, purity or germinating quality. Detroit gardeners have offered green peas grown from our stock several days in advance of any other. Our stocks are of the best. All smooth peas 60 pounds per bushel; all wrinkled peas 56 pounds per bushel. Wrinkled varieties marked thus*.

\section{EXTRA EARLY SORTS.}

First and Best. Height two and a.half feet. The best extra early pea ever offered. Thls variety is unequaled for excellence, yield, size of pod and regularity of growth. It is a prodigious bearer, and ripens up so evenly as not to require more than two pickings to clear off the crop, and in this last feature and in its extreme earliness con. sists its great value to market gardeners and truckers.

Extra Early. Height two and a-half feet. One of the best early peas, largely used by southern gardeners.

Extra Early Kent. Height three feet. A favorite early variety.

Alaska. Height two and a-half feet. The earliest blue pea; a fine sort; popular with canneis and market gardeners; ripens uniformly.

*American Wonder. Height one foot. Extra early. Dwarf-growing vines, quality su. perb. A splendid sort for home use.

*McLean's Little Gem. Height one and a. half feet. This variety is nearly as early as the American Wonder, and the vine is decidedly larger and bears an im. mense crop of pods, which are larger and invariably well filled with peas of the best quality. Market gardeners use more of this sort than any other wrinkled pea.

*Premium Gem. Height one and a-half feet. A very desirable early. dwarf. green. wrinkled variety, When in a green state it is very large, sweet and of delicious flavor. SECOND EARLY SORTS.

* McLean's Advancer. Height two and a half feet. This pea is used very extensively by the market gardeners in the vicinity of De. troit on account of its great productiveness, the fine appearance of its pods, and its fine flavor.

Telephone. Height two feet. Market gardeners have found it a most profitable sort. The vines often bear eighteen to twenty pods per stalk, each containing six or seven large peas,

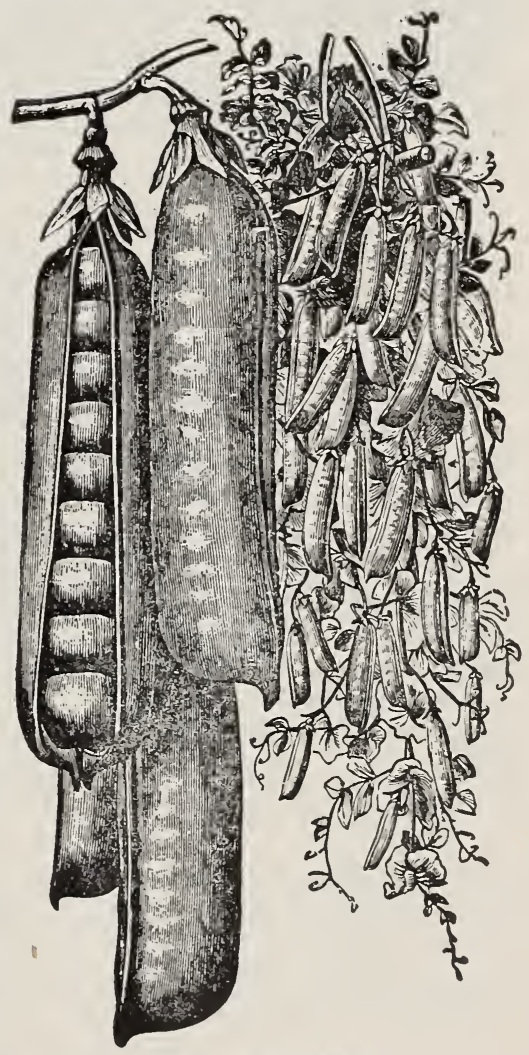

PEAS, First and Best. of excellent flavor. Our stock has been most carefully selected and can be relied upon.

*Shropshire Hero. Height two and a-half feet. This valuable, new, second early wrinkled pea is a decided improvement on the old Yorkshire Hero.

*Yorkshire Hero. Height two and a-half feet. A splendid, large marrow pea; abundant bearer, fine quality.

\section{LATE SORTS.}

*Champion of England. Height five feet. This is yet, by general consent, acknowl. cdged to be the best of the late tall varieties.

Large White Marrowfat. Height five feet. Strong growth; pods large, cylindrical, rough, light color and well filled.

Large Black Eye Marrowfat. An excellent variety, pods large; a prolific bearer.

Melting Sugar. Height three feet. (Edible Pods.) it should be used in much the same way as a wax bean. 


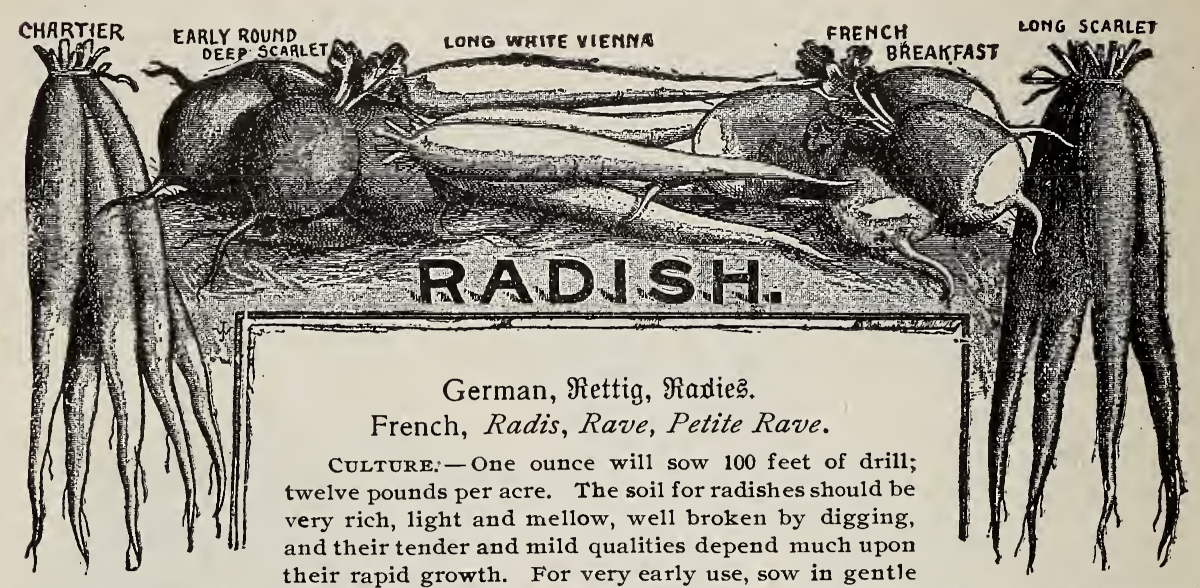

hot-beds in February, and in the open air as soon as the ground can be worked, at intervals of ten or $t$ welve days for a succession, as long as they may be wanted. The winter varieties should be sown in August and lifted before severe frost, and stored in the cellar.

\section{EARLY ROUND RADISHES.}

Non Plus Ultra, or Early Deep Scarlet Turnip, Forcing. This has as small a top and is as early as any variety in cultivation, making it one of the best for forcing. Roots fit for use may be had in three weeks or less from time of sowing.

Early Scarlet Turnip, White Tipped. A handsome, very early round sort; skin bright scarlet on top and shading to white on the bottom; crisp and fine; very popular.

Early Scarlet Turnip, White Tipped, Forcing. A very beautiful forcing variety; similar in shape and appearance to Scarlet Turnip, White Tipped.

Early Round Deep Scarlet. An early, round, deep scarlet-skinned variety; crisp and tender.

Early Scarlet, Turnip Rooted. A well-known early turnip-shaped variety; very quick grower.

Early White, Turnip Rooted. Good for forcing or open ground.

Early Scarlet Globe. This variety makes roots fit to pull as early as Non Plus Ultra, but they are much larger when full size, and for this reason are very popular in some markets.

French Breakfast. Pink color, olive shape, white tipped; popular everywhere.

Large White Summer Turnip. A very handsome round or turnip-shaped variety; grows large size; skin and flesh pure wh ite, very crisp and fine flavored.

Golden Globe. A perfect globe in shape; skin bright golden yellow; rapid grower and fine quality; a good variety for summer.

\section{EARLY LONG AND SUMMER RADISHES.}

Wood's Early Frame. An excellent, long, red radish, not quite so long as the Long. Scarlet, with smaller top, and is quite a few days earlier; fine either for forcing or equally as good for open ground.

Long White Vienna, or Lady Finger. Early, of rapid growth and beautiful shape; skin and flesh snow white; very juicy, firm, crisp and tender; the finest of long white radishes.

Early Long Scarlet, Short Top, Improved. This is a standard variety for private garden or market use. It grows six to seven inches long, half out of the ground; is very brittle and crisp, and of quick growth; color bright scarlet; top small.'

Improved Chartier, or Shepherd. A very handsome and attractive variety, tender and crisp, and does not become pithy or hollow for a long time after attaining its full growth. Its shape is long, being of a deep crimson at the top and shading off to white at the bottom. Largely used by southern truckers. 
Long Brightest Scarlet, White Tipped. New and distinct. Color vivid scarlet, tipped with snow white.

White Naples. Skin and flesh pure white; mild and pleasant flavored; for summer and fall.

White Strasburg. This grows to the largest size and is usable when quite small, thus covering a long season. The mature roots are four or five inches long and about two inches thick; very white; the flesh is exceedingly crisp and tender. One of the best of the large summer sorts.

WINTER RADISHES.

Scarlet China Winter. Bright rose-colored skin; flesh white and quality excellent; one of the best for fall and winter use; a favorite with market men.

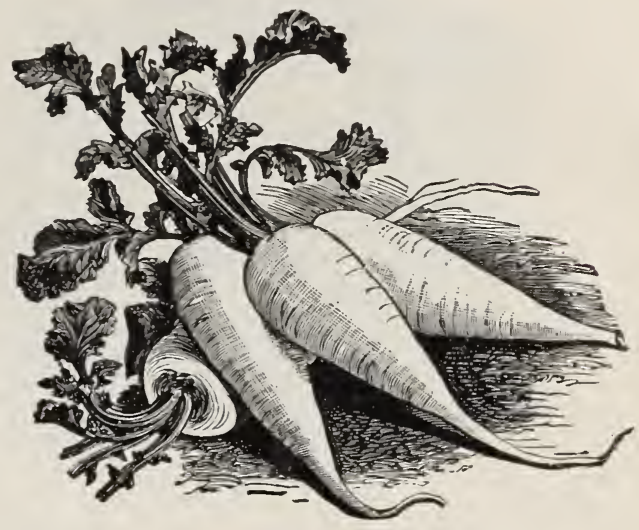

Long White Spanish. Flesh white, solid and pungent, though milder than Black Spanish.

Long Gray Laon. Similar to the last except in color.

Long Black Spanish. A long, black-skinned variety; flesh white and slightly pungent; one of the latest and hardiest.

\section{Salsify, \\ Or Oyster Plant.}

German, FodfßGart. French, Salsifis.

Culture.-One ounce will sow fifty feet of drill; eight pounds per acre. Sow the seed in light, deep soil, early in spring, in drills 12 inches a part and one inch deep, thinning out the young plants to four or five inches. The roots will be ready for use in October, when a supply should be taken up and stored like carrots. Those remaining will suffer no injury by being left in the ground till spring.

Mammoth Sandwich Island. We consider this the largest and most profitable salsify in cultivation; roots are two or three times the size of the ordinary salsify, and of more agreeable flavor. It is pure white in color, and invaluable to market gardeners.

\section{Spinach.}

German, Spinat. French, Espinard.

CULTURE.-One ounce for 100 feet of drill; fifteen pounds broadcast per acre. The main crop is sown in September. It is sometimes covered up in exposed places with straw during winter, which prevents it from being cut with frost; but in sheltered fields therc is no necessity for covering. For summer use it may be sown at intervals of two or three weeks from April to A ugust.

Long Standing, Thick Leaved. An improved round-seeded strain of excellent merit, having all the good qualities of the ordinary sorts. It is especially desirable because it goes to seed much later than any other variety. It is adapted for both spring and fall sowing, and is one of the best for market and family use.

Savoy Leaved. Hardy and prolific.

Round Leaved. A standard variety.

Improved Thick Leaved.

Prickly Winter Long Standing. The hardiest variety; thick leaved. For fall sowing.

\section{Sun Flower.}

Large Russian. This variety has large heads, having much more and larger seed than the common sort. Grows almost invariably to a single unbranched stalk.

Connecticut Seed Leaf. A popular sort.

\section{Tobacco Seed.}

Havana, Finest strain of imported seed. 


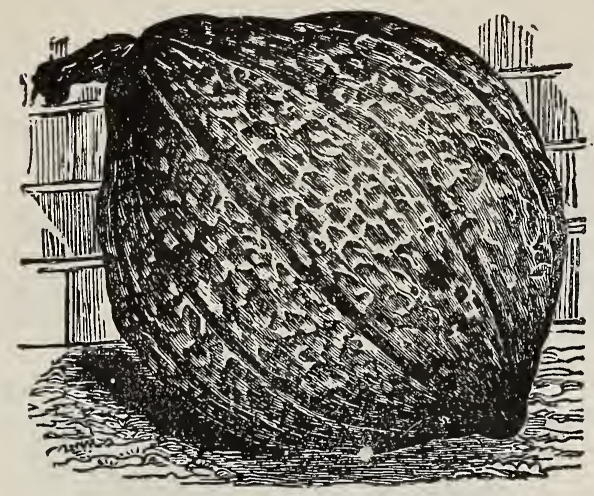

SQUASH, Boston Marrow.

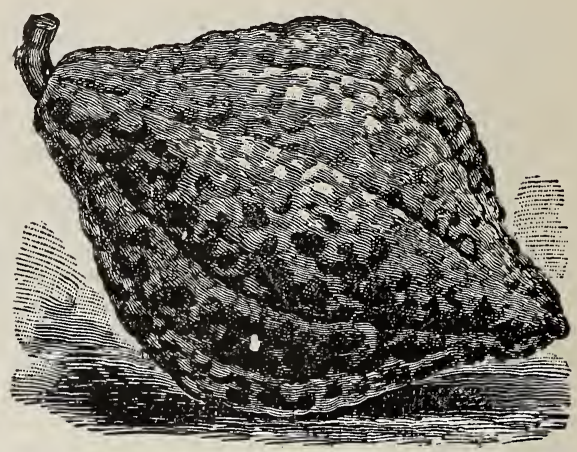

SQUASH, Hubbard.

\title{
Squash.
}

\author{
German, $\mathfrak{i u ̈ r b i z . ~ ' F r e n c h , ~ C o u r g e . ~}$
}

CULTURE.-Bush sorts one ounce for 50 hills; bush varieties two pounds, and running varieties three pounds in hills for an acre. Squashes are of luxuriant and vigorous growth, and athough they will grow readily on almost any soil, they will well repay generous treatment. L,ike all vegetables of this class, it is useless to sow until the weather has become settled and warm. Light soils are best suited for their growth, and it is most economical of manure to prepare hills for the seeds in the ordinary manner by incorporating two or three shovelsful of well-rotted manure with the soil for each hill. For the bush varieties, from three to four feet each way, and for the running sorts from six to eight feet. Eight or ten seeds should be sown in each hill, thinning out after they have attained their rough leaves, leaving three or four of the strongest plants.

\section{SUMMER VARIETIES.}

Early White Bush Scallop. A standard summer variety; good either for home or market garden.

Early Yellow Bush Scallop. Same as White Bush excepting colo،

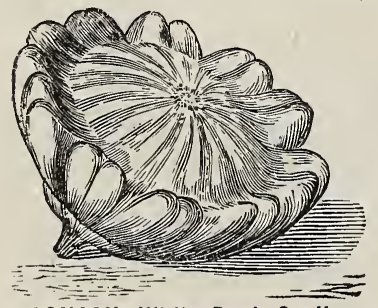

SQUASH, White Bush Scallop.

Mammoth White Bush Scallop. The best strain of white scalloped squash in existence. It grows to a large size, and for quality is simply delicious.

Mammoth Summer Crookneck. It is twice as large as the ordinary Summer Crookneck, far more warty and several days earlier. This combination of earliness, large size and wartiness, which adds so much to its attractiveness, makes it altogether the most desirable squash for the market or private garden.

\section{AUTUMN OR WINTER VARIETIES.}

Boston Marrow. Fine fall variety, oval, bright orange; flesh yellow and firm; best for pies and also for canning.

Hubbard. This is a superior variety, and the best winter squash known; flesh bright orange yellow, fine grained, very dry, sweet and rich flavored; keeps perfectly good throughout the winter; boils or bakes exceedingly dry, and is esteemed by many to be as good baked as the sweet potato. We have taken the utmost pains with this sort and can recommend our stock as in all probability the best in the country, and think our customers can plant it with perfect confidence that every fruit will be a pure Habbard. 


\title{
Tomato.
}

\author{
German, biebesapfel. French, Tomate.
}

Culture.-One ounce will produce 1500 plants; two ounces per acre. The tomato is raised from seed, which should be sown in the hot-bed about February 20 , and continuous sowings made until April 1 , according as the plants are wanted for use. When the plants are ahout two inches high, transplant to four inches apart; and, after three or four weeks, transplant from the hot-bed into a cold-frame, setting the plants eight inches apart each way.

\section{EARLIEST RED VARIETIES.}

Atlantic Prize. One of the earliest; smooth, solid and bright red.

Early Michigan. Ripens its first fruit almost as early as any sort; fruit medium size to large, and unlike most varieties grows larger as the season advances; perfectly smooth, soiid, deep, rich, red color, and of excellent flavor.

Livingston's Favorite. Large, smooth, productive and a good shipper.

Trophy. Very solid and good in every way; bright red color; a standard late sort.

Livingston's Perfection. A splendid spherical tomato for canning or shipping, blood red, has few seeds.

Livingston's New Stone. This new sort is a great favorite with canners. Vine vigorous and productive. Fruit round, apple-shaped, very large, very deep red in color, and astonishingly heavy.

\section{PURPLE FRUITED VARIETIES.}

Luvingston's Acme. Earliest of the purple fruited sorts. Vines large, hardy and pro

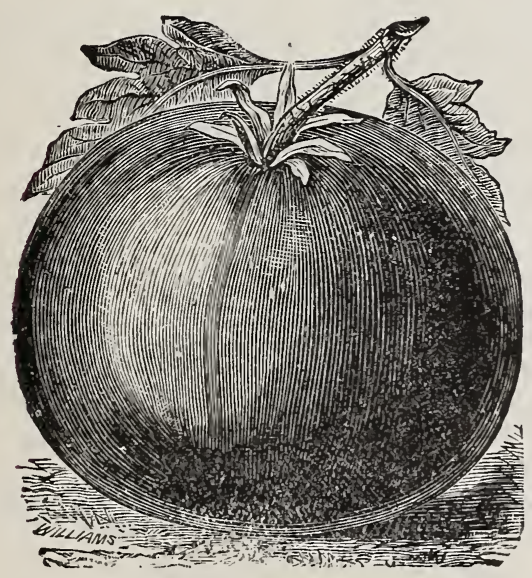

TOMATO, Livingston's Acme. ductive, ripening its first fruit almost as early as any, and continuing to bear abundantly until cut off by trost. Fruit in clusters of four or five, invariably round, smooth and of good size, free from cracks and stands shipment remarkably well; flesh solid and of excellent flavor. For market gardeners who want an early purple fruited tomato, either for home, market or to ship, tor private gardens or for canners, it stands without a peer among its class.

Essex Early Hybrid. Very similar to the Acme, fruit slightly darker purple, always smooth and handsome; quality among the best.

Dwarf Champion. The branches are short, making a bushy plant that stands quite erect without stakes. Th is sort is often sold as Tree Tomato. Colos purplish.pink, fairly solid. About as early as any purple tomato.

Livingston's Beauty. Large, smooth. pinkish-red; thick flesh, regular form.

\section{MISCELLANEOUS VARIETIES.}

Peach. Resembles a peach in size and shape; color red; fine for preserves, pickles and for exhibition.

Golden Queen. Yellow, ripens early, is large sized, smooth and solid.

Yellow Plum. Fruit plum-shaped, clear deep yellow color. 


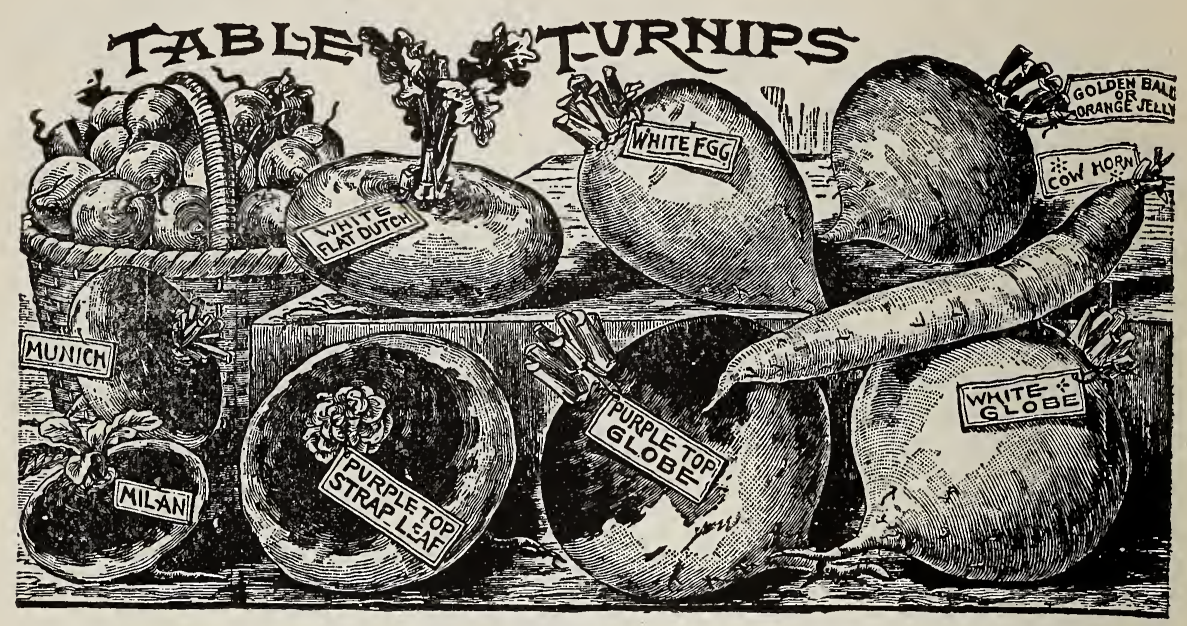

\section{Turnip.}

German, Rübe. French, Navet.

CULTURE.-One ounce will sow 150 feet in drills: one pound per acre. For early use, sow as soon as the ground can be worked in spring, in drills 15 inches apart, and thin to eight inches apart, as soon as plants a re large enough to handle. For succession, sow at intervals of $\varepsilon$. fortnight until the last week of July, from which time until the end of August sowings will be made for main and late crops. The sowings should always be done just before rain if possible, a rapid growth being important.

\section{WHITE FLESHED SORTS.}

Extra Early Purple Top Milan. The earliest turnip in cultivation and a splendid variety; a favorite with gardeners who want first turnips in market. Bulb white, flat, of medium size, with a bright purple top.

White Egg. Its shape is nearly oval or egg; flesh very firm and fine-grained, thin and perfectly smooth skin, and both flesh and skin are of snowy whiteness.

Early White Flat Dutch, Strap Leaf. A flat white sort, very sweet and fine-grained; excellent for garden culture and most beautiful.

Red, or Purple Top, Strap Leaved. The most widely cultivated and best known variety. Used largely for sowing broadcast among corn and potatoes. It is round and flat, white on the bottom and a reddish purple above ground, and a very quick grower. Though used mainly for stock-feeding, it is highly esteemed as one of the finest table varieties.

Purple Top White Globe. An early variety, globe-shaped; heavy cropper; in other respects similar to the Red Top Strap Leaf. A handsome-looking bulb, and is rapidly taking the lead of all other varieties of early turnip for market garden purposes.

Large Red Top Norfolk. A handsome, spherical or slightly flattened root, reddishpurple above ground, with small top. Grown both for table use and stock.

Pomeranian White Globe. A large globe-shaped white variety; in good soil will grow to weigh twelve to fifteen pounds. Used mainly for feeding stock.

Cow Horn, or Long White. Roots carrot-shaped, and grows half above ground; flesh is firm, white and sweet, and is a good table variety.

Sweet German. It partakes largely of the nature of the ruta baga, and should be sown a month earlier than the flat turnips. The flesh is white, hard, firm and sweet.

\section{YELLOW FLESHED SORTS.}

Large Amber Globe. Flesh yellow, fine grained and sweet; color of skin yellow.

Orange Jelly, or Robertson's Golden Ball. Not of large size, but firm, hard, and of most excellent flavor. Keeps well, and is superior as a table variety.

Purple Top Yellow Aberdeen. Flesh pale yellow, tender and sugary. 


\section{Ruta Baga, or Swedish Turnip.}

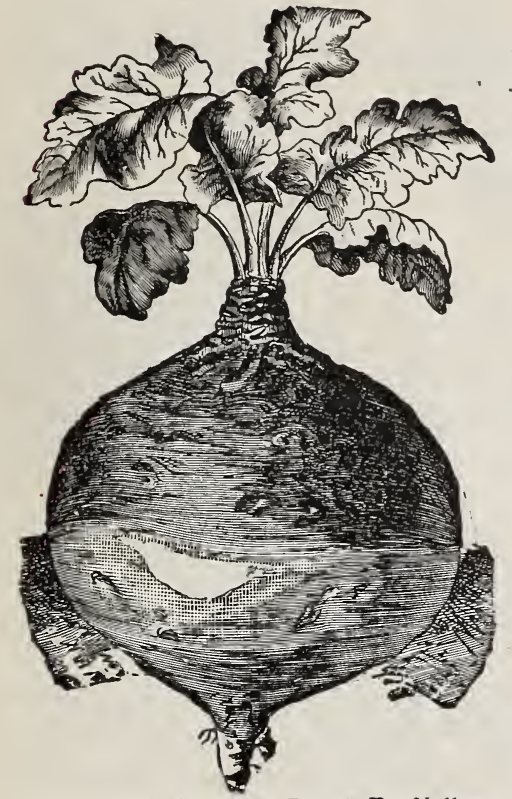

Culture,-One ounce will sow r 50 feet of drill; one purnc per acre. Should be sown from the 2oth of June to the middle $o_{1}$ $J u l y$, in drills two feet apart, and thinned out at the first work: $n_{\text {: }}$ to ten inches between the plants.

American Purple Top Yellow, or Long Island. This strain is of American origin, bred to a smaller top and short neck. Bulbs are of great size, yellow fleshed and purple crown.

Improved Purple Top, Yellow. Flesh yellow, of solid texture, sweet and well flavored; shape slightly oblong, terminating abruptly; color deep purple above and bright yellow under the ground. Has but little neck.

Yellow Swede. Shape oblong; dull reddish co!o: above ground, but yellow underneath.

Carter's Imperial Purple Top Flesh yellow, solid, firm, sweet and rich. It is a hardy sort, yields heavily.

Monarch or Tankard. This is a yellow fleshed sort, having very large tankard shaped roots, with relatively small necks and tops. This variety is sold also as Hurst's Monarch and Carter's Elephant.

Sweet Russian, or White. Grows to a very large size; flesh white, solid, of firm texture, sweet and rich; an excellent keeper.

RUTA BAGA-American Purple Top Yellow.

\section{Sweet Herbs.}

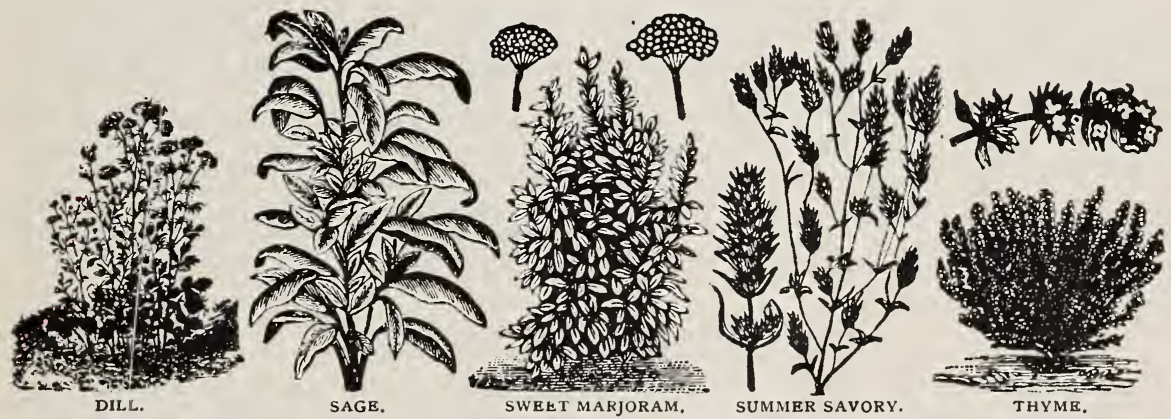

Basil. The leaves are used for flavoring soups, stews, and highly-seasoned dishes.

Borage. The leaves are used for flavoring.

Dill. The seeds have an aromatic odor and warm pungent taste. They are used for pickling with cucumbers.

Lavender. An aromatic, medicinal herb.

Marjoram. A perennial plant, but not hardy enough to endure the winter of the North. The young, tender tops are used green for flavoring, or they may be dried for wintes use. Sow in drills as early as possible, and thin out the plants to ten inches apart.

Rosemary. The aromatic leaves are used for seasoning.

Sage. A hardy perennial, cultivated for use as a condiment; it being used more extensively than any other herb for flavoring and dressing. Sow early in spring on very rich ground, cultivate often and thin the plants to sixteen inches apart.

Summer Savory. A hardy annual, the dried stems, leaves and flowers of which are extensively used for flavoring, particularly in dressings and soups. Culture the same. as that of Sweet Marjoram.

Thyme. This herb is perennial. The young leaves and tops are used for soups, dressing: and sauce. Sow as early as the ground will permit. 


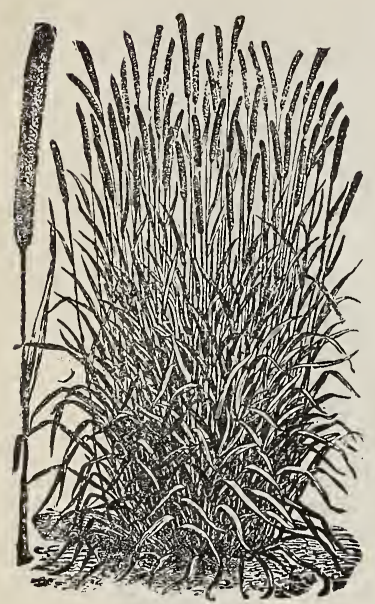

TIMOTHY.

\section{WE ARE HEADQUARTERS}

\section{FOR HIGH=GRADE RE=CLEANED GRASS SEED.}

TIMOTHY.

This is the most valuable of all the grasses for hay, especially in the North. Thrives best on moist loamy soils of medium tenacity. It should be cut just when the blossom falls. Sow early in the spring or fall, at the rate of twelve pounds per acre, if alone, but less if mixed with other grasses. Forty-five pounds per bushel.

RED TOP-FANCY

In some sections this is called Rhode Island Bent Grass. In Pennsylvania and states farther south it is known as Herd's Grass, a name applied in New England and New York to Timothy. It is a good, permanent grass, standing our climate well, and makes good pasture when fed close. Sow in spring or fall.

\section{KENTUCKY BLUE GRASS.}

Sometimes called June, but the true June or Wire Grass is much inferior. The Kentucky Blue Grass is the most nutrious, hardy and valuable of all northern grasses In Conjunction with white clover it forms a splendid lawn; for this purpose use four bushels of Blue Grass and six pounds of White Clover per acre. If sown by itself for pasture, two bushels will be required; sow early in the spring, or in October or November. Fourteen pounds per bushel.

\section{ORCHARD GRASS.}

One of the most valuable grasses on ac-

\section{Clover}

MAMMOTH, OR LARGE RED.

Grows nearly twice the size of the common Red Clover, often making a stand when the other clovers fail. Sow about eight pounds per acre.

\section{MEDIUM RED, OR JUNE.}

This is by far the most important of all the varieties for practical purposes. Sow in spring or fall; and if no other grasses are used. at the rate of eight to ten pounds per acre; more is required on old stiff soils than on new and lighter ones.

\section{ALSIKE, OR SWEDISH.}

The most hardy of all clovers; perennial. on rich, moist soils it yields an enormous quantity of hay or pasturage, but its greatest value is for sowing with other clovers and grasses, as it forms a thick bottom and greatly increases the yield of hay. Sow in spring or fall, at the rate of six pounds per acre, when used alone.

\section{CRIMION TRFFOIL, OR SCARLET}

ITALIAN.

An annual variety. The yield in fodder is immense, and after cutting, it at once com- count of its quick growth and valuable aftermath. It has a tendency to grow in tufts, and does better if sown with clover, and as it ripens at the same time the mixed hay is of the best quality. When sown alone, two bushels are required per acre; if sown with clover, half that amount. It is perennial, and will last for years, but its habit of growth unfits it for lawns. - Fourteen pounds per bushel.

\section{PERENNIAL RYE GRASS.}

A very valuable variety for permanent pasture. Succeeds well on almost any soil, but is particularly adapted to moderately moist or irrigated lands. It is largely used, mixed with other grasses, for lawns. Sow 30 to 40 pounds per acre, in spring.

\section{HUNGARIAN.}

This is a species of annual millet, growing less rank, with smaller stalks, often yielding two or three tons of hay per acre. It is very popular and valuable with those who are clearing timber lands. Sow and cultivate like millet.

\section{COMMON MILLET.}

Requires a dry, light, rich soil, and grows two and a half to four feet high, with ? fine bulk of stalks and leaves, and is cellent for forage. For hay, sow broadcasi about 25 pound per acre, from May 1st to August 1st.

\section{GERMAN, OR GOLDEN MILLET.}

An improved variety, medium early, growing three to five feet high. The heads are closely condensed, though the spikes are very numerous. The seeds are contained in rough, bristly sheaths and are round, golden-yellow and beautiful in appearance.

\section{Seeds.}

mences growing again, continuing until severe, cold, freczing weather. It grows about one foot high; leaves long, blossoms long, pointed and of a very deep red, or carmine color. It is sown in August or September in the South, but should not be planted in the North until Spring.

\section{WHITE DUTCH.}

A small, creeping perennial variety, valuable for pasturage and for lawns. It accommodates itself to a variety of soils, but prefers moist ground. Sow in spring, at the rate of six pounds per acre, or when used with other grasses, half that amount.

\section{LUCERNE, OR ALFALFA.}

It is useless to sow this clover on land having a stiff clay or hard pan sub-soil as the roots naturally penetrate to a great depth, and must do so if the plants live any time. Sow on rich, moist loam or sandy soil, having a deep porous sub-soil. Prepare the land thoroughly and sow seed at the rate of fifteen to twenty-five pounds per acre. 


\section{PLANET

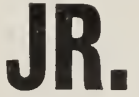

Send for Complete Illustrated Descriptive List of these Invaluable Tools. IT IS FREE. : : :

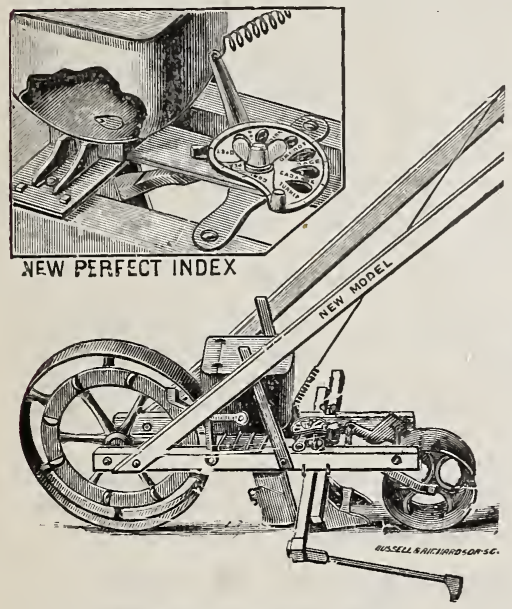

NEW MODEL SEED DRILL.

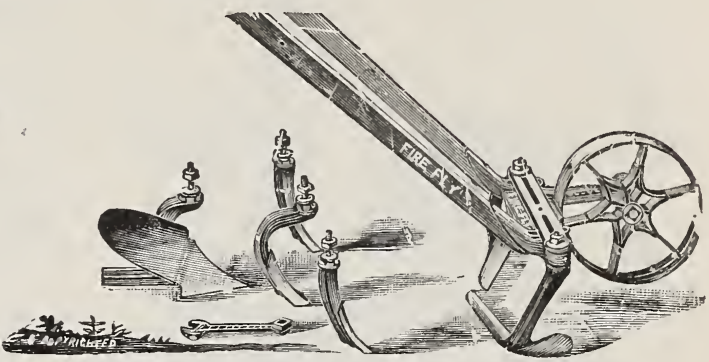

PLANET Jr., FIREFLY SINGLE WHEEL HOE.

Planet Jr. Plain Double Wheel Hoe............... \$4.00

Planet Jr. Single Wheel Hoe, Cultivator, Rake and

Plow ............................. 5.00

Planet Jr. Single Wheel Hoe, with I Pair Hoes, only, 3.25

The Firefly Single Wheel Hoe, Cultivator and Plow, 425

The Firefly Wheel Garden Plow..... ........ 2.25

The Planet Jr. Grass Edger . ..................50

Horse Hoe and Cultivator..... . ... .......... $\mathbf{6 . 5 0}$

The Weed Slayer............................. 2.00

The New Model Se€d Drill, Unquestionably the Best Drill on the $\$ 7.00$ Planet Jr. No. 2. Seed Drill, - - $\quad$ - 7.00 The Planet Jr. Combined, DRILL, WheEL HOE, Cultivator, 9.50 The Mage€ Cultivator, Try One and You Will Use No Other, $\quad \mathbf{3 . 0 0}$ Gem of the GardeD Caltivator $\quad$ - $\quad 4.25$ The Plapet Jr., Double WheEL HOE, CULTIVATOR, $=\quad 6,50$

\section{CHOICE SEED POTATOES.}

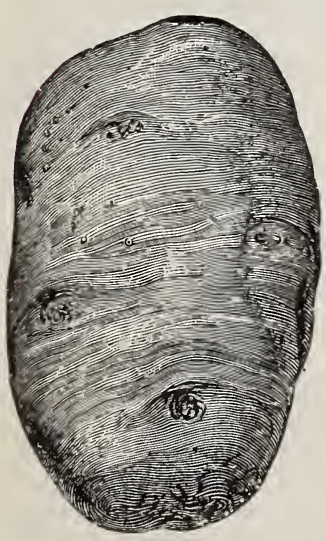

EXTRA EARLY MARKET POTATOE.

Culture.-Twelve to 14 bushels to the acre; one peck will plant about 125 hills. Plant in hills or ridges about three feet a part, covering in light, warm soil about four inches deep, but in cold or wet situations, two-and-a-half or three inches will be sufficient. Soil best suited is a sandy loam.

Early Ohio. Now widely known and deservedly one of the most popular sorts. It has the advantage of being fit for use and sale even before fully ripe. A few days earlier than the Early Rose and similar in color and habit of growth. Quality dry and mealy. Peck, 35 cents; bushel, \$1.25.

Extra Early Market. Is from ten days to two weeks earlier than Early Rose or Beauty of Hebron, while fully one week earlier than the Early Ohio and nearly twice as produc: tive. The potatoes are uniformly of good size, free from rough or scabby tubers; oblong in form, very smooth, eyes set well on the surface, skin creamy white, slightly shaded with pink. The flesh is pure white, remarkably fine grained, and always of the best table quality. The tubers grow very compactly in the hill, with strong foliage of dark green. It is a sure cropper, immensely productive, and will undoubtedly become the standard extra early Potato. Peck, 40 cents; bushel, $\$ 1.50$. 


\section{SWEET PEAS.}

CULTURE_Early in spring make a trench, about six inches deep, in rich, mellow soil, so arranged that no water can stand in it, and plant the seed in the bottom, taking care not to cover it more than two inches. When the plants are about five inches high, fill up the trench, and furnish some support for the vines to run upon. The flowers should be picked before they form pods, or the plants will soon stop flowering.

Per Pkt. 5c; Oz. 10c; I/4 Lb. 25c.

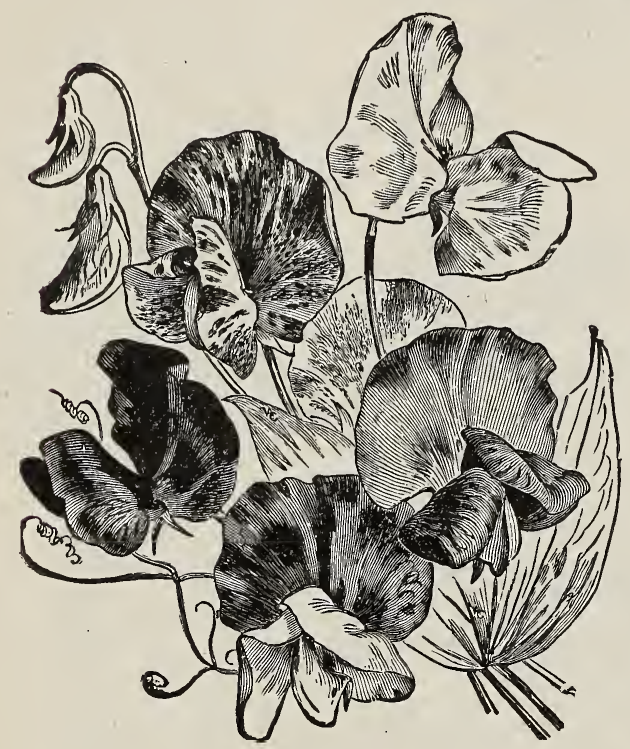

WHITE.

BLANCHE BURPEE. A sFlendid pure white variety. The individual flowers are very fine, making it a very desirable sort for florists.

EMILY HENDERSON. A bold, well formed, clear white flower. Wings broad and well expanded. An early and wonderfully free and persistent bloomer.

INVINCIBLE WHITE. A fine strain of pure white.

\section{LIGHT YELLOW.}

LEMON QUEEN. Buds and back of standard tinted yellow. When fully expanded the flower is a delicate pink, the standard very large, round with gracefully waved edges.

MRS. ECKFORD. Plant strong-growing and vigorous; stems three and four flowered; flowers large, of great substance and perfect form. A delicate shade of primrose yellow at first, becoming nearly white at maturity.

METEOR. Standard bright orange-salmon; wings pink, veined.

PRIMROSE. Standard medium sized, rather long. yellowish-white in front, and pronounced primroseyellow on the back; wings large and nearly white.

\section{LIGHT SHADES OF PINK.}

ELIZA ECKFORD. Large flower of rosy pink over white, giving an exceedingly delicate and beautiful effect.
KATHERINE TRACY. The color is soft but brilliant pink, of precisely the same shade in wings and standard. Its form is perfect and the strong-growing plants are vigorous, and give a wonderful profusion of flowers which continue large and fine until the end of the season. In hardiness, prolific flowering habit, durability and practical usefulness this is greatly superior to most sorts of recent introduction.

MRS. GLADSTONE.-Standard very large, thick and finely formed, brilliant, but soft rose-pink; wings large, nearly same shade as standard.

MRS. SANKEY. Standard round, very thick, delicate shell-pink; wings a little lighter than standard. Although often described as a pure white, we consider this one of the most beautiful of the pink varieties, only becoming white as it fades.

VENUS. Standard large, of fine form and substance; a brilliant but delicate and soft shade of warm rosepink and buff; wings similar to the standard.

\section{DARKER SHADES OF PINK.}

APPLE BLOSSOM. Standard rose-pink, lighter at the base; wings lighter than standard.

ORANOB PRINCE. Standard pink suffused with yellow; wings bright light pink.

PEACH BLOSSOM. A very large flower having a warm yellowish-pink standard and wings of a lighter softer shade.

ROYAL ROSE. One of the largest and finest formed flowers yet produced. Standard a deep rose pink; wings a lighter shade of the same color.

\section{RED OR ROSE STANDARDS WITH LIGHTER WINGS.}

EXTRA EARLY BLANCHE FERRY. Standard deep rose pink, with nearly white wings; the earliest sweet pea.

BLANCHE FERRY. Standard medium sized, but of fine form and bright pink color; wings large, rounded and nearly white.

\section{SHADES OF RED.}

FIREFLY. Very bright and intense crimson scarlet of good size and form.

INVINCIBLE SCARLET. Bright scarlet.

SPLENDOUR. Standard very broad, a rich, deep rose-pink; wings large and bluer but lighter than standard.

\section{CLARET AND MAROON.}

BOREATTON. One of the darkest and richest colored. Standard large, rounded; rich satin-like maroon; wings are similar in colcr to the standard.

STANLEY. A very beautiful sort, standard large, and flat, color a deep maroon and warmer than Boicatton. 


\section{SWEET PEAS - Continued.}

\section{LAVENDER AND LIGHT BLUE.}

BUTTERFLY. Standard a combination of shades of violet and lavender; it is often notched on the sides. Wings white, shaded and edged with blue.

cOUNTESS OF RADNOR. Self colored in a very distinct and beautiful shade of lavender. Our stock of this splendid variety is reselected and is sometimes sold by other seedsmen as "Countess."

DOROTHY TENNANT. Flowers warm violet or mauve, very large and finely formed. Standard broad, incurved or hooded; wings very large, rounded.

LOTTIE ECKFORD, Standard a peculiar and delicate shade of magenta blue; wings very large, long and shaded; lavender deepening to violet at edge.

\section{BLUE AND PURPLE.}

CAPTAIN OF THE BLUES. Standard large, broad, bright purple-blue; wings expanded, lighter and brighter blue than standard.

INDIGO KING. Standard very rich purple maroon; wings bluer than the standard.

\section{STRIPED OR VARIEGATED.}

GRAY FRIAR. Very large, finely shaped flowers of delicate mauve color, peculiarly tinged, marbled and dotted with darker shade. Quite distinct.

MRS. JOSEPH CHAMBERLAIN. Very large and perfect shaped flower; white; striped with bright rose carmine

\section{DWARF VARIETIES.}

WHITE CUPID. Grows eight inches high.

PINK CUPID. Similar in color to Blanche Ferry. Grows eight inches high.

\section{CHOICE MIXED.}

This mixture consists only of the choicest sorts, new and old, in just the right proportion of white, bright red, pink, mauve and other colors to make the most brilliant show possible in the garden. We have given a great deal of study to selecting the best sorts and in proper proportions and offer this mixture as the finest we are capable of producing. We know it cannot be excelled at any price.

\section{NASTURTIUMS.}

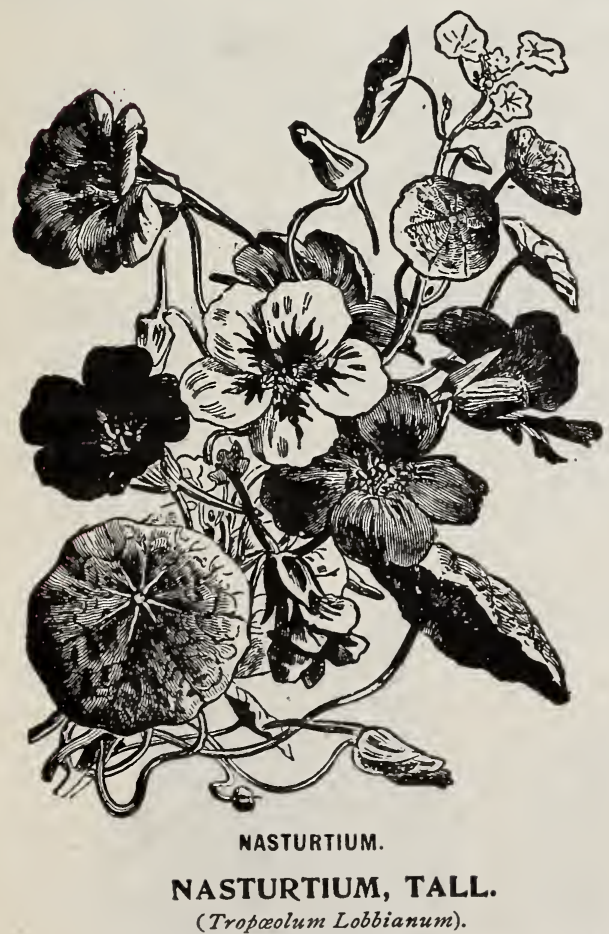

The Lobbianum differs from the common running nasturtium, in being less rank growing, more floriferous, and having richer, more varied colored flowers of many shades, from the richest scarlet to very deep maroon. Fine for covering arbors, trellises and rustic work. Half hardy annual; about ten feet high.
Bright Yellow, with carmine stain .........Pkt. 5c Brilliant, intense red ................ " $5 \mathrm{c}$ Cardinal, dark scarlet..... $\quad . . . \ldots \ldots .$. . $_{5} \mathrm{c}$ Chestnut Brown..................... "4 $5 \mathrm{c}$ Giant of Battles, bright red............. " $5 \mathrm{c}$ King of the Blacks, crimson-maroon, with darker markings.................... " $5 \mathrm{c}$ Light Yellow, with rich maroon stain........ " 5 c Spltfire, bright fiery red, very floriferous...... " $5 \mathrm{C}$ mixed, Tall (Lobbianum varieties).......... $1 / 20 z$. IOc; I Oz. I5c; " $5 \mathrm{c}$

\section{NASTURTIUM, DWARF.}

\section{(Tropoeolum Minor).}

A bed of dwarf nasturtiums in the yard is very brilliant and attractive, blooming all the season. Hardy annual; about one foot high.

Aurora, light reddish-orange, veined with

carmine .............................. Pkt. 5c

Bronze Colored ....................... " $5 \mathrm{c}$

Crlmson, rich dark crimson ............... " $5 \mathrm{c}$

Empress of India, brilliant dark scarlet ..... “ " 5c

King Theodore, dark scarlet-maroon........ " $5 \mathrm{c}$

King of Tom Thumbs, scarlet-orange....... " $5 \mathrm{c}$

Ochre Yellow, golden yellow ............ " $5 \mathrm{c}$

Pearl, pale yellow...................... " 5c

Rose............................... " $5 \mathrm{5}$

Scarlet, scarlet-orange ................ " 5c Schiling's Striped, bright yellow, with maroon stripes........................... " $5 \mathrm{c}$ Yellow........................... " $5 \mathrm{c}$ Mlxed Dwarf ......... I $/ 20 z$. IOc; I Oz. 15c; " $5 \mathrm{c}$

\section{NASTURTIUM.}

Madame Gunter's Hybrids. The flowers of this variety are striped or blotched with shades of red on yellow and orange ground, forming a combination of exceeding brilliancy and beauty............. Pkt. 5c 


\section{SUMMER FLOWERING BULBS.}
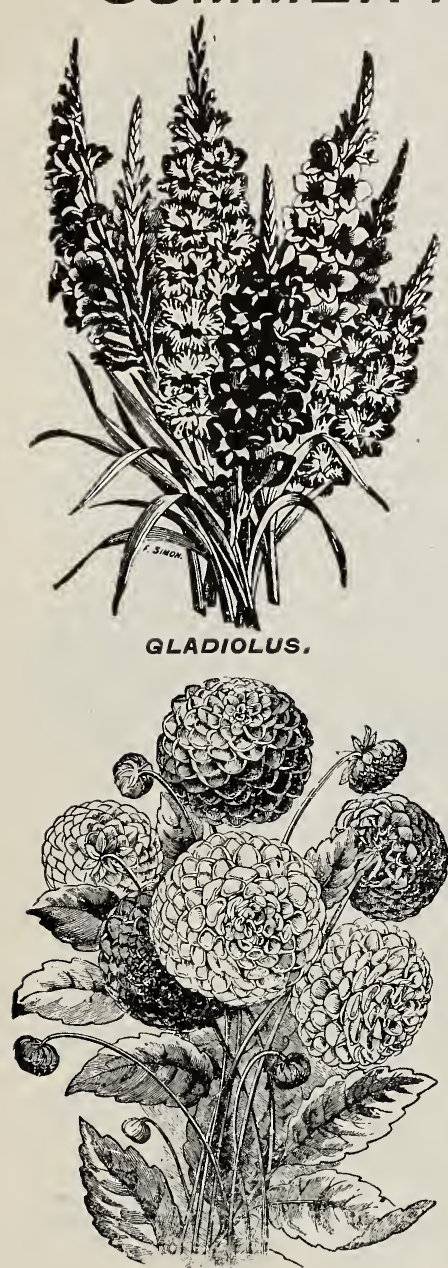

DAHLIA.

\section{CALADIUM.}

ELEPHANT'S EAR-Magnificent sub-tropical plants; when planted out in beds or as single specimens on lawns they have a grand appearance.

Small bulbs, 5 c. each; 50c. per doz.

Second size bulbs, Ioc. each; $\$ 1.00$ per doz.

Large bulbs, 15c. each; \$1.50 per doz.

\section{GLADIOLUS.}

One of our finest summer-blooming bulbs. The flowers are of many shades of color. Plant at intervals of two weeks during the spring, thus providing a succession of bloom from summer until frost. Of the easiest culture.

Extra fine Hybrids mixed, 3c. each; $25 \mathrm{c}$ per doz.

Shades of Pink mixed, 3c. each; 3oc. per doz.

Shades of Red mixed, 3c. each; zoc. per doz.

Shades of Yellow mixed, 5c. each; 50c. per doz.

White and Light Varieties, 5c. each; 5oc. per doz.

Striped and Variegated mixed, 5c. each; 50c. per doz.

Lemoine's Butterfly Varieties mixed, 4c. each; 40c. per doz.

\section{DAHLIAS.}

Stately and handsome autumn-blooming flowers, of perfect form and wide range of color. Plant out in spring after danger of frost.

\section{DOUBLE, TALL AND POMPON OR CACTUS. W}

Pink, Scarlet, White, Yellow, Variegated and Mixed, 15c. each; \$1.50 per doz.

\section{CHOICE FRENCH CANNAS.}

A strikingly beautiful effect is presented by their brilliant immense flower heads. They begin blooming early in June and continue until late in September.

roc. each, 3 for $25 \mathrm{c} ; \$ \mathrm{I}$.00 per doz.

AUSTRIA. 6 feet. Very large flowers and foliage. Flowers canary yellow, spotted with brownish red.

ALPHONSE BOUVIER. 6 feet. Large trusses of vivid crimson flowers.

CHARLES HENDERSON. 4 feet. Flowers crimson; petals wide and well rounded.

EGANDAI. 4 feet. Bronze leaves. Flowers currant red. EXPLORATEUR CRAMPBEL. 5 feet. Flowers vermillion scarlet with crimson spots.

FLORENCE VAUGHAN. 4 feet. Broad green leaves. Flowers yellow, dotted with bright red. MADAM CROZY. 4 feet. Scarlet flowers bordered with gold.

PAUL MARQUANDT. 4 feet. Extra large flowers of a deep salmon color.

QUEEN CHARIOTTE. $3^{\mathrm{T} / 2}$ feet. Broad, green leaves. Large, rich scarlet flowers with a wide golden band around each petal.

\section{LILIUM AURATUM.}

Extremely fragrant and very beautiful. Flowers white, dotted with crimson, with a golden band running through center of each petal.

10c. each; 3 for 25c.; $\$$ I.00 per doz.

DOUBLE PEARL TUBEROSES.

3c. each; 3oc. per doz.

\section{BEGONIAS, TUBEROUS ROOTED.}

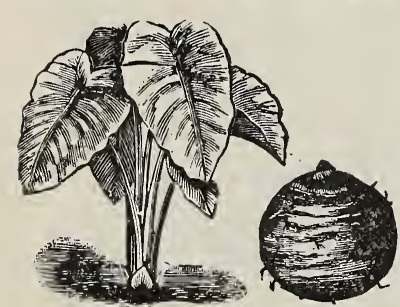

CALADIUM.

The flowers often measure six inches across and are much more brilliant than the most dazz1ing Geraniums.

Colors Separate. Single rose, white, scarlet, yellow or pink, 10c. each, 3 for 25 ; $\$ 1.00$ per doz.

\section{PAEONIES.}

Rose and Crimson, 15c. each. White, 20c. each.

MADEIRA VINE.

3c. each, 4 for 10c.; 30c. doz.

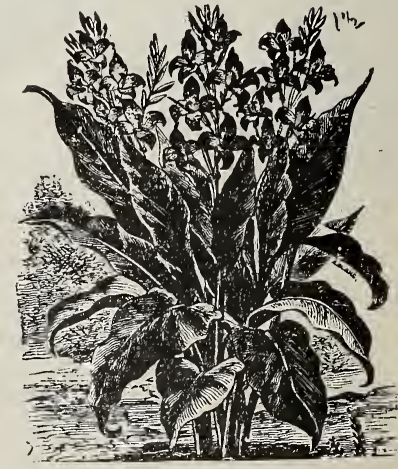

CANNA. 


\section{FLOWER SEED LIST.}

We offer below a select list of seed of the most desirable species and varieties of flowering plants. Florists will do well to hand us their orders in this line as we make thir wants a special study, and aim to keep nothing but the very best seeds of the finest varieties.

All varieties are arranged in alphabetical order with cross references to the more common synonyms. Such biennials and perennials as are more satisfactory treated as annuals, we have designated as annuals in this list.

Abobra Viridiflora, tender perennial climber, height Is feet, should be treated as an annual, flowers

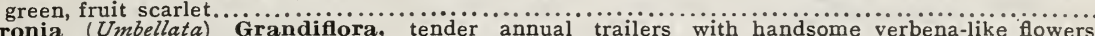
Abronia (Umbellata) Grandifora, tender annual trailers with handsome verbena-like flowers,

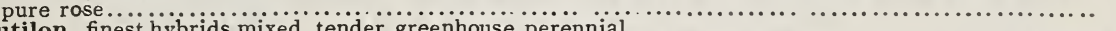
Abutilon, finest hybrids mixed, tender greenhouse perennial..................... herght ${ }_{4}$ it., flowers blue.

Acroclinium, double mixed, half hardy annuals, $z$ ft. high, whose dry flowers make "everlastings"....... Adlumia Cirrhosa, hardy biennial, ornamental climber, with pink and white flowers, foliage fern

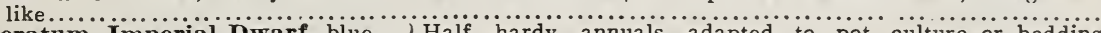
Ageratum, Imperial Owarf, blue, Half hardy annuals adapted to Dot culture or bedding Althea, see Hollyhock.

Alyssum Saxatile Compactum, dwarf, golden yellow flowers, hardy perennial, I ft. high, fine for edgings......................................... $\mathrm{O} z .25$ cents ..... " Maritimum, (Sweet Alyssum) hardy annual, I ft. high, flowers white........ I/ $\mathrm{O} z$. Io cents.... Benthami Compactum Erectum (Little Gem), very dwarf, hardy annual, flowers

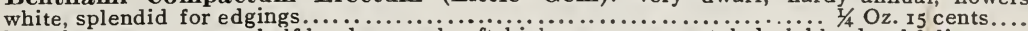
Amaranthus Atropurpureus, half hardy annual, $3 \mathrm{ft}$. high, very ornamental, dark blood red foliage.... Tricolor, (Joseph's Coat), half hardy annual, $3 \mathrm{ft}$. high, handsome foliage, plant

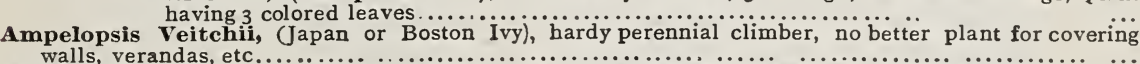

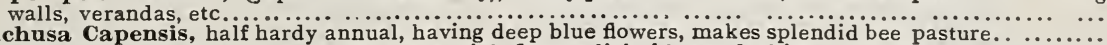

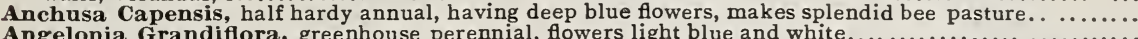

Antirrhinum Majus, (Snapdragon), tall mixed, half hardy annual, start in heat and transplant to

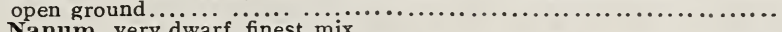

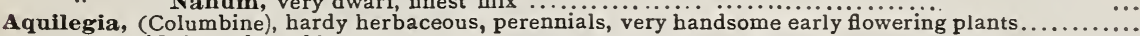

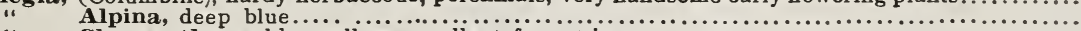

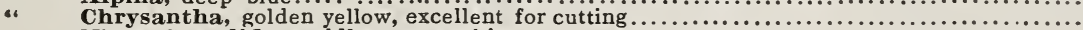

“ Nivea Grandiflora Alba, pure white..

Aristolochia Sipho, (Dutchman's Pipe), hardy deciduous twiner, $30 \ldots \ldots \ldots \ldots \ldots \ldots \ldots \ldots \ldots \ldots . \ldots \ldots$ large, ornamental leaves and "pipe" like flowers....

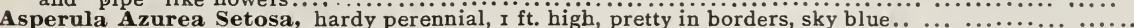

Asters, half hardy annuals, forming an indispensible feature of every private garden and among the most useful of florists flowers.

most useful of florists flowers.

Chrysanthemum Flowered, dwarf, choice mixed.

German Quilled, mixed...

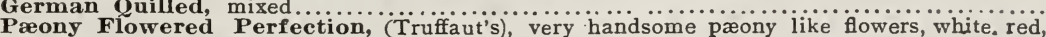

rose, sky blue, in separate colors .....................................

Victoria, the queen of all the Aster family, indispensible to florists, white, scarlet, rose, light

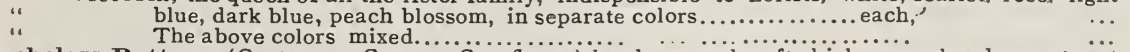

Bachelors Buttons, (Centaurea Cyanus, Cornflower) hardy annual, 2 ft. high, very handsome, tnest

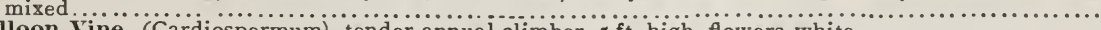

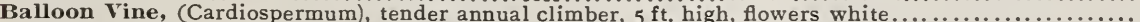

Balsams, half hardy annuals, fine for the open border, called by some "Lady Slipper"

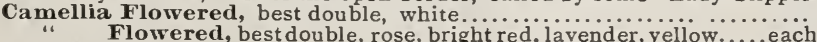
Dwarf, double mix.....
"“

Balsam Apple, (Momordica) tender annual creepers, io ft., fruits resemble an a pple, sow in frame and treat like cucumbers.

Bartonia Aurea, half hardy annual, $\mathrm{i} 8$ inches high, having large golden yellow flowers, very desirable

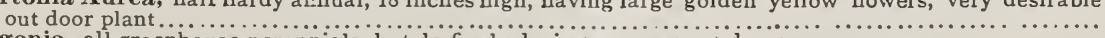

Begonia, all greenhouse perennials, but do finely during summer out doors.

Semperflorens Atropurpurea, Vernon, flowers brilliant red, foliage green and bronze,

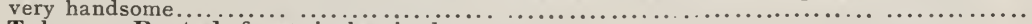

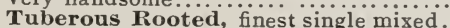

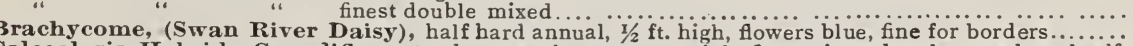
Calceolaria Hybrida Grandiflora, tender greenhouse perennial, finest tigered and spotted, and self-

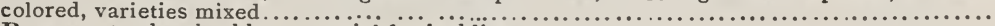
Rugosa, tender shrubby perennial for bedding... . . . . . . . . . . . . . . . . . . . . . . . . . . . . . . . .

Pkt.

5 
Calendula, (Marigold), hardy annuals, I ft. high, an indispensible feature of every garden.

“" Prince of Orange, double yellow flower, very profuse bloomer...............

Calliopsis or Coreopsis.

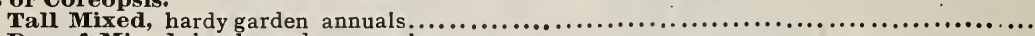

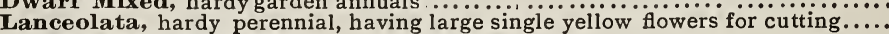

Campanula, see Canterbury Bell.

Canary Bird Flower, (Tropæolum Canariense) tender annual climber, to feet high. having bandsome canary yellow flowers .........................................................

Candytuft, (Iberis), hardy annuals, I ft. high, planted much in borders and valuable 1 or pouquets.

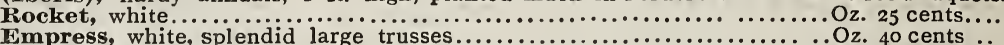

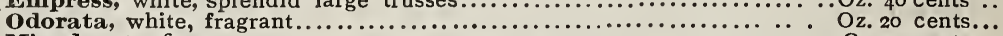

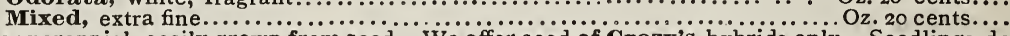

Canna, tender perennial, easily grown from seed. We offer seed of Crozy's hybrids only. Seedlings do not come true to parent color necessarily, though should give a fair proportion of desirable flowers.

Mad. Crozy

President .............

Crozy's, mixed varieties

Canterbury Bell, sINGLE MIXED, hardy biennials, $3 \mathrm{ft}$. high, flowers blue, white, rose. large fiowerıng...

Cardiospermum, see Balloon vine.

Carnations, green house perennials, fine for bedding out during summer.

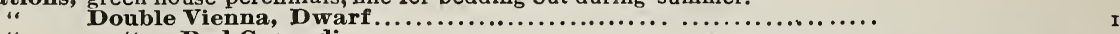

“ Margaret, very early, will filower in four to five months from sowing, seed $1 / 2$ dwarf,

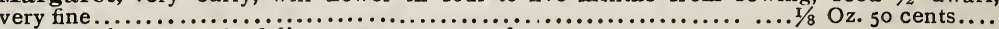

Castor Bean, tall growing. annuals, foliage very ornamental.

Borboniensis, tallest of all $\ldots \ldots \ldots \ldots \ldots \ldots \ldots \ldots \ldots \ldots \ldots \ldots \ldots \ldots \ldots \ldots, 20$ cents $\ldots \ldots$

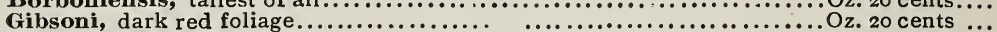

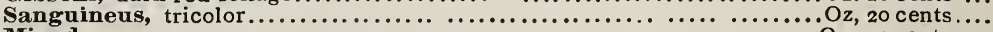
Mixed.

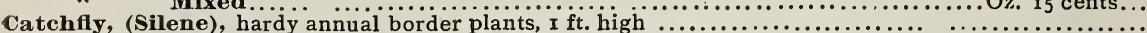

Centaurea Candidissima, (Dusty Miller), half hardy annual, silver white foliage, ornamental for

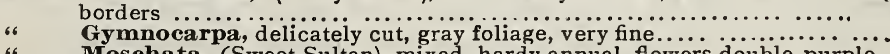

Moschata, (Sweet Sultan), mixęd, hardy annual, flowers double purple.

Chryanthemums, hardy and half hardy annuals and perennials; much used for garden and house decoration and for cut flowers.

" Coronarium, Mixed, hardy annual.

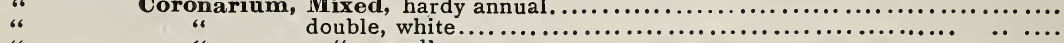

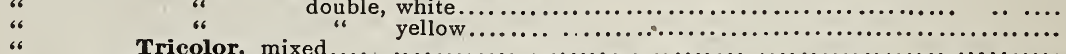

"6 Tricolor, mixed ... $\quad$ Frutescens, (White Paris Daisy), half hardy perennial, having an abundance of

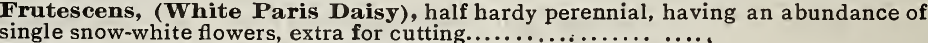

66 Inodorum, double, white, perennial, much used for cutting......

Chieranthus, see Stock.

Pkt.

Cineraria, greenhouse perennials, very ornamental.

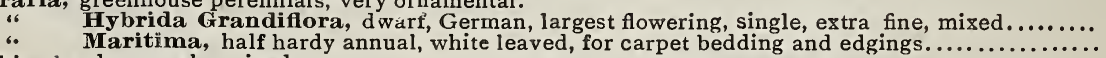

Clarkia, hardy annuals, mixed.

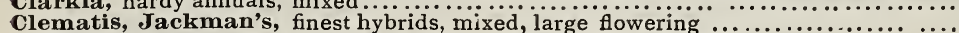

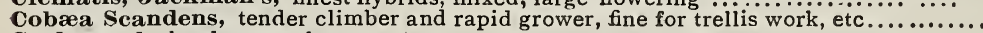

Cockscomb, hardy annuals.

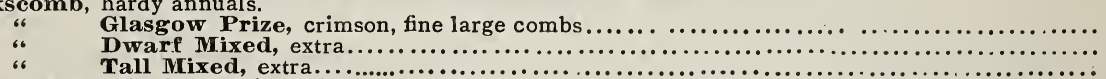

Coleus, finest mixed, French stock................................... Per rooo seeds 50 cents....

Columbine, see Aquilegia.

Convolvulus, Morning Glory, hardy annuals.

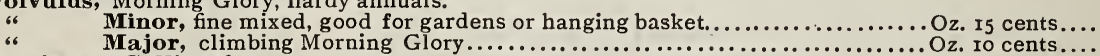

Coreopsis, see Calliopsis.

Cosmos, tender annua.ls, large growing and should be started in heat in March.

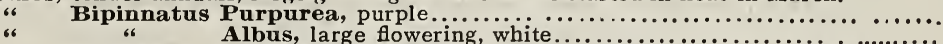

" Albus, large flowering, white
Cyclamen Persicum Giganteum, Grandifiorum,

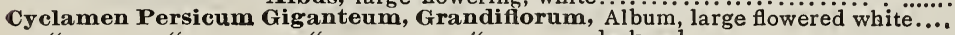

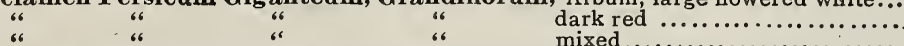

" Persicum, mixed, good stock.

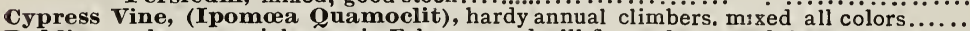

Dahlia, tender perennials, sow in February and wlll flower from seed the same year.

.66 Single, finest mixture.

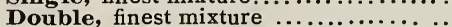

Daisy, hardy annuals, splendid bloomers, 6 in. high

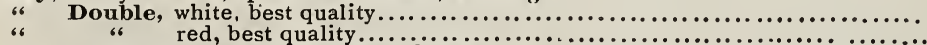

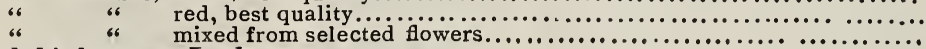

Delphinium, see Larkspur.

Dianthus, hardy and half hard perennials.

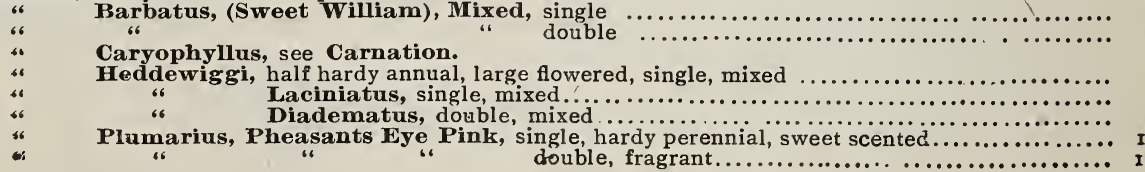


Dizitalis, (Foxglove) Gloxinzeflora, fine spotted, hardy perennials.

Dolichos Lablab, Hyacinth Beans, half hardy twiners, flowers purple and white....

Dracæna Mazeli, dark green, rose centre.

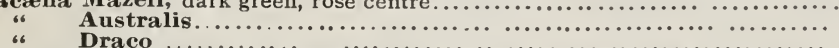

Eschscholtzia Californica, California Poppy, hardy annuals, fine mixed.

Evening Primrose, see Oenothera.

Feverfew, (Matricaria) double white,

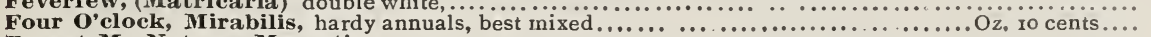

Forget-Me-Not, see Myosotis.

Fox Glove, see Digitalis.

Fuchsia, fine mixed hybrids.

Gaillardia Picta Lorenziana, hardy annual, double fine mixed

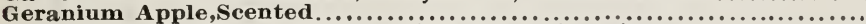

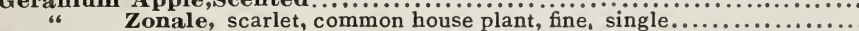

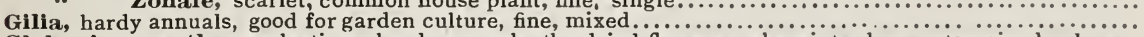

Globe Amaranth. everlastings, hardy annuals, the dried flowers make winter bouquets, mixed colors. .

Gloxinia Hybrida Crassifolia Grandiflora Erecta, greenhouse perennials, finest mixed

Gourds, ornamental climbers, annuals, orange, pear shaped, striped, siphon or dipper, white egg shaped.

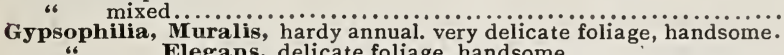

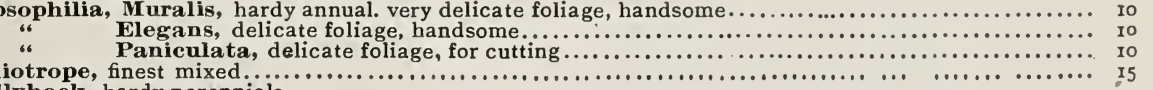

Hollyhock, hardy perennials.

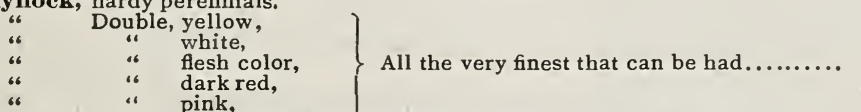

" " mixed, the above varieties mixed...

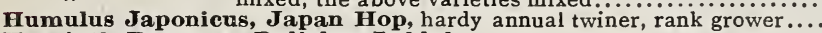
Hyacinth Bean, see Dolichos Lablab.

Ice Plant, Mesembryanthemum.

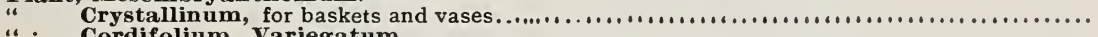

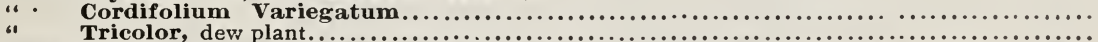

Ipomoea, annual twiners having large handsome flowers, one of the best for verandas, trellis work, etc.

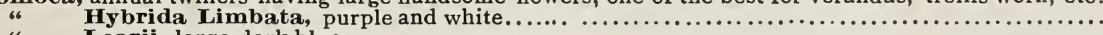

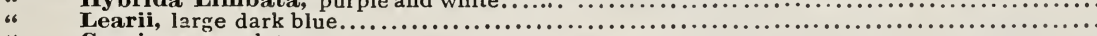

"6 Coccinea, scarlet.

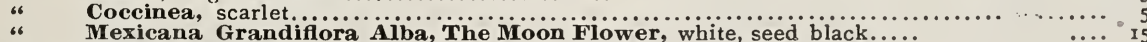

"6 Mexicana Grandiflora Alba, The Moon Flower, white, seed black.....

Joseph's Coat, see Amaranthus.

Job's Tears, (Coix Lachryma)...

Kenilworth Ivy, see Linaria.

Lantana Hybrida, fine mixed.

Larkspur, Delphinium.

“6 Dwarf, Double Rocket, hardy annual.

6. Tall, Double Rocket, hardy annual.

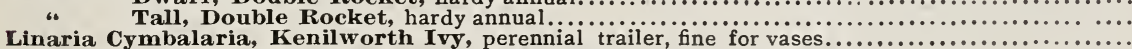

Linum Grandiflorum, Searlet Flax, hardy annual $\ldots$

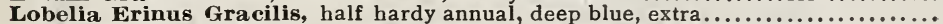

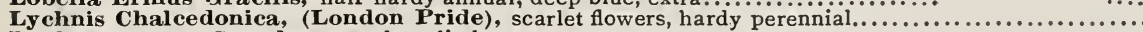

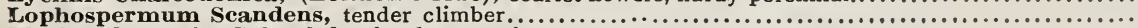

Marigold, see also Calendula, hardy annuals.

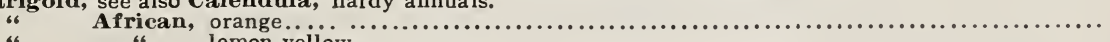

"6 lemon yellow...

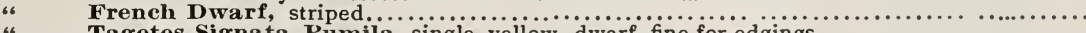

Taurandia, climbers, tine mixed

Mesembryanthemum, see Ice Piant.

Mignonette, (Reseda), hardy annuals, large flowering, sweet, common mignonette...... Oz. Io cents...

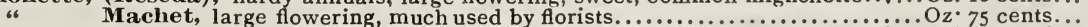

Red Victoria, makes a thicker, more compact truss than $\mathbf{M a c h e t}$ and is the best variety

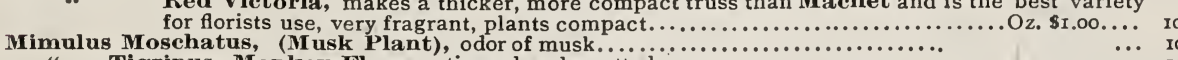

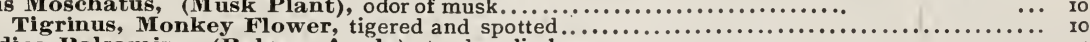

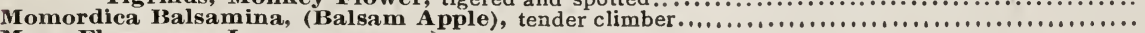

Moon Flower, see Ipomca.

Morning Glory, see Convolvulus.

Myosotis, Forget-Me-Not, splendid plants for edgings and borders.

Nasturtium, half hardy annuals.

"6

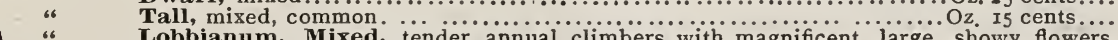

Lobbianum, Mixed, tender annual climbers with magnificent, large, showy flowers.

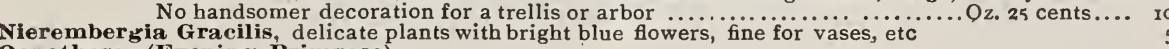
Oenothera, (Evening Primrose).

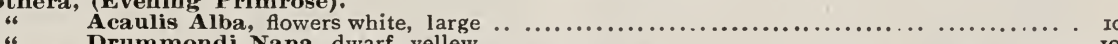

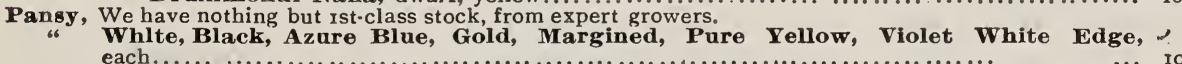

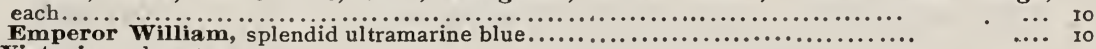

Victoria, red, extra. .

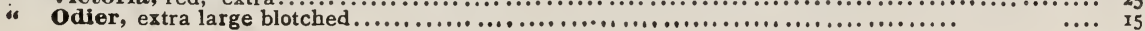


“Trimardeau Giant, Zirngiebel's select strain. We consider this one of the best stocks of this

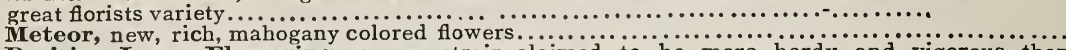
Parisian Large Flowering, a new strain claimed to be more hardy and vigorous than

Peas, Everlasting, hardy perennial climbers, should be in every garden, pure white, crimson and rosy

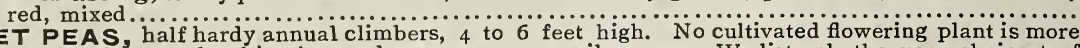
SWEET PEAS, half hardy annual climbers, 4 to 6 feet high. No cultivated flowering plant is more
worthy of general cultivation and none are more easily grown. We list only the very choicest of the numerous varieties now grown.

“ Emily Henderson, (See page 2I), new satiny white variety, far the best white yet introduced. The seed we offer is in Peter Henderson \& Co.'s original sealed packets....

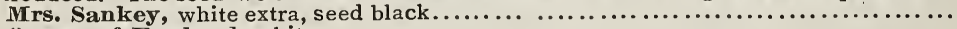

Queen of England, white.

Blanche Ferry

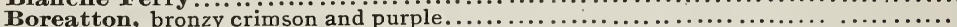

Princess Beatrice, delicate rose, beautiful.....................................

Indigo King, dark purple.

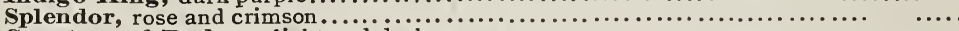

Countess of Radnor, light and dark mauve.

Mrs. Gladstone, buff and pink, extra.

Delight, white and cardinal...

Invincible Carmine, crimson scarlet.

Primrose, delicate shade primrose, beautiful.

Butterfly, lavender, one of the handsomest...

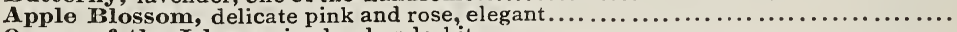

Queen of the Isles, striped red and white.

Pure White, excellent quality.

Extra Fine Mixed, this is made up of the above splendid varieties, there is

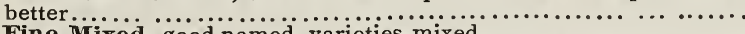

Fine Mixed, good named, varieties mixed.....................

Petunia, half hardy annuals for bedding or pots.

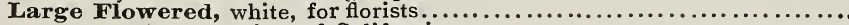

Giant of California....

Superb, single, mixed ...............................

Double, mixed, splendid.

Phlox Drummondi $\cdot$ Grandiflora, hardy annuals, should be in every collection.

"،

nk, see Dianthus.

white, chamoise rose, scarlet................

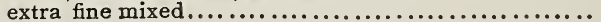

Pink, see Dianthus,
Poppy, hardy annuals for out door planting.

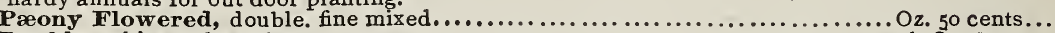

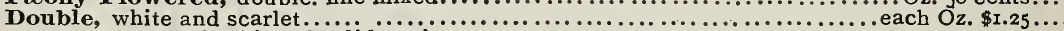

Golden Gate, mixed in splendid variety.

“ The Shirly, extra fine, mixed .

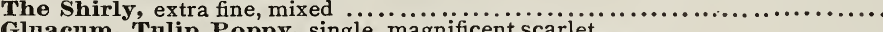

Gluacum, Tulp Poppy, single, magniticent scarlet.....
Portulaca, half hardy annuals, elegant for massing in large beds.

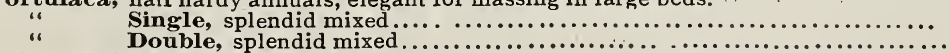

Primula, (Primrose) Sinensis.

Single, Large Flowering, white, Fern leaved

“" Single, Large Flowering, white, Fern leaved

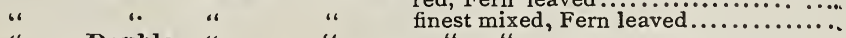

Double, “

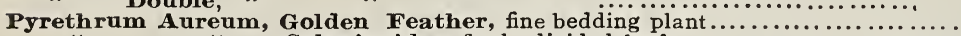

Selaginoides, finely divided leaf.

Serotinum, (Leucanthemum Uliginosum, ) white cut flower, blooms first year from

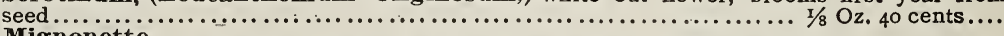

Reseda, see Mignonette.

Salpiglossis, no better bedding plant for the amateur gardener, showy and floriferous.

Finest Hybrids Mixed, large flowering.

Salvia Splendeus, fiery scarlet, beautiful lawn decoration.

Scabiosa, hardy annuals, extra for cutting.

White

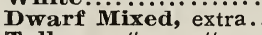

Tall,

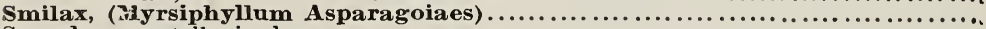

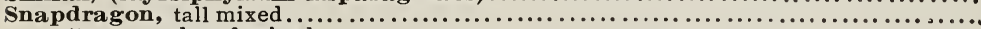

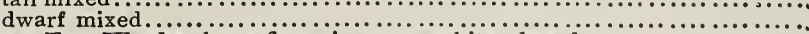

Stocks, German Ten Weeks, large flowering, pure white, dwarf $\ldots \ldots \ldots \ldots \ldots \ldots \ldots \ldots \ldots$
"6

Sunflower, Californica, double.

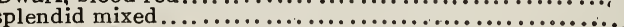

Sweet William, see Dianthus.

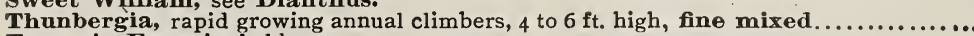

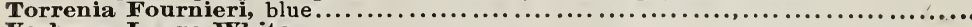

Verbena, Large White.

"Scarlet Defiance.

Mammoth, mixed

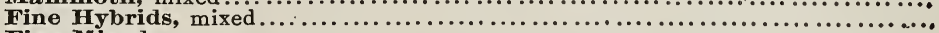

Vinca, Fine Mixed.

Wallfower, Mixed, Single.........

Finnia

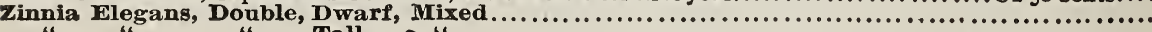

Pkt. Io cents I5 "

I5

"1

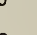




\section{WhOLESALE PRICE LIST}

FOR

\section{GARDENERS AND FARMERS.}

If sent by mail, postage must be added; 8 cents per pound; 10 cents per pint; 15 cents per quart. Price per packet, 10 cents for Peas, Beans and Corn. Price per packet, 5 cents for Vegetable Seeds.

\section{ASPARAGUS.}

Palmetto ..................10 ${ }^{2} \mathrm{Oz}_{\mathbf{1 5}}{ }^{1 / 4} \mathrm{Lj} . \mathrm{Lb}_{\mathbf{7 5}}$ Conover's Coilossai..........10 15 15 35 Tro-year-old Roots, per $100, \$ 1.00$.

\section{BRUSSELS SPROUTS.}

Best English

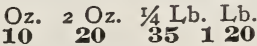

\section{BEANS.}

Dwarf Butter or Wax Podded Varieties.

Pt. Qt. 2 Qt. 4 Qt. Pk. Bu.

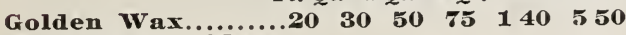
Wardwell's Kidney

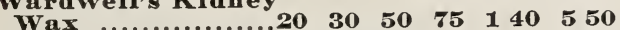

Prolific German

$\begin{array}{lllllllll}\text { Wax } \ldots \ldots \ldots \ldots \ldots \ldots 20 & 30 & 50 & 85 & 1 & 60 & 6 & 00\end{array}$ Challenge Dwarf

Black Wax.........20 $30 \quad 50 \quad 85 \quad 150 \quad 600$

\section{Green Podded Varieties.}

Pt. Qt. 2 Qt. 4 Qt. Pk. Bu.

Refugee, or Thou$\begin{array}{lllllll}\text { sand to one......15 } & 20 & 35 & 60 & 90 & \mathbf{3} & 60\end{array}$ Early Kidney, Six

$\begin{array}{llllllll}\text { weeks } & & & \end{array}$

Royal Dwari Kid-

ney ..............10 $20 \quad 30 \quad 50 \quad 80 \quad 300$

Large white Mar-

row ...............10 20 30 $50 \quad 50 \quad 300$ $\begin{array}{llllllll}\text { Early } & \text { Iarrow Pea10 } & 20 & 30 & 50 & 75 & \mathbf{3} & 00\end{array}$

Henderson's Bush

$\begin{array}{llllllll}\text { Lima } & \ldots . . . \ldots \ldots \ldots . .20 & 35 & 65 & 1 & 10 & 200 & 700\end{array}$

Burpee's Bush

$\begin{array}{llllllllll}\text { Lima } & \ldots \ldots \ldots \ldots \ldots 25 & 40 & 70 & 1 & 25 & 225 & 8 & 00\end{array}$

Pole or Running.

Early Jersey

Pt. Qt. 2 Qt. 4 Qt. Pk. Bu. $\begin{array}{lllllll}\text { Lima } \ldots \ldots \ldots \ldots . . . . .20 & 35 & 65 & 110 & 200 & 700\end{array}$ Seibert's Eariy

$\begin{array}{llllllllll}\text { Limg } & \ldots \ldots \ldots \ldots \ldots 20 & 35 & 65 & 1 & 10 & 200 & 7 & 50\end{array}$ rargewhite Lima.20 35 50 $85160 \quad 600$ King of the Gar-

den Lima.........20 $35 \quad 60 \quad 100 \quad 200 \quad 650$ Dutch Case Knife.20 $35 \quad 65110200 \quad 700$

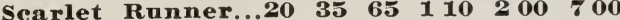
London Horticultaral

\section{BEET.}

\begin{tabular}{|c|c|c|}
\hline Lohrman's Egyptian & 15 & 20 \\
\hline Extra Early Egyptian....10 & $\mathbf{1 5}$ & 15 \\
\hline Early Eclipse..............10 & $\mathbf{1 5}$ & $\mathbf{1 5}$ \\
\hline Crosby's Egyptian..........10 & $\mathbf{1 5}$ & $\mathbf{1 5}$ \\
\hline Columbian Red Turnip...10 & & 20 \\
\hline & 15 & \\
\hline $\begin{array}{l}\text { Detroit Dark Ked Tur- } \\
\text { nip } \ldots \ldots \ldots \ldots \ldots \ldots \ldots \ldots \ldots \ldots\end{array}$ & & \\
\hline Dewing's Early rurnip...to & 15 & 15 \\
\hline Turnip Bassano.......... & & \\
\hline Half Long Blood... & 15 & 15 \\
\hline Long Dark Blood.... & 15 & \\
\hline Swiss Chard... & 15 & 15 \\
\hline
\end{tabular}

Mangel Wurzel and Sugar Beets.

Oz. $1 / 4$ Lb. Lb. 5 L,bs.

Improved Mammoth Long:

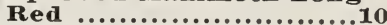

Golden Täikard................

Yellow ovoid or inter-

mediate ..................10

Orange Globe................

Red Globe...................10

French white sugar,

Red Top..................10

Lane's Imperiai Sugar.....10

French Yellow Sugar....10

Vilmorin's Improved Im-

perial sugar..............10

Klein Wanzleben............10

$\begin{array}{llll}10 & 30 & 1 & 25\end{array}$

$1030 \quad 125$

$\begin{array}{llll}10 & 30 & 1 & 25\end{array}$

1025100

$10 \quad 30 \quad 1025$

1025100

$\begin{array}{llll}10 & 25 & 100\end{array}$

$1030 \quad 1.25$

$10 \quad 22100$

1022100

CABBAGE.

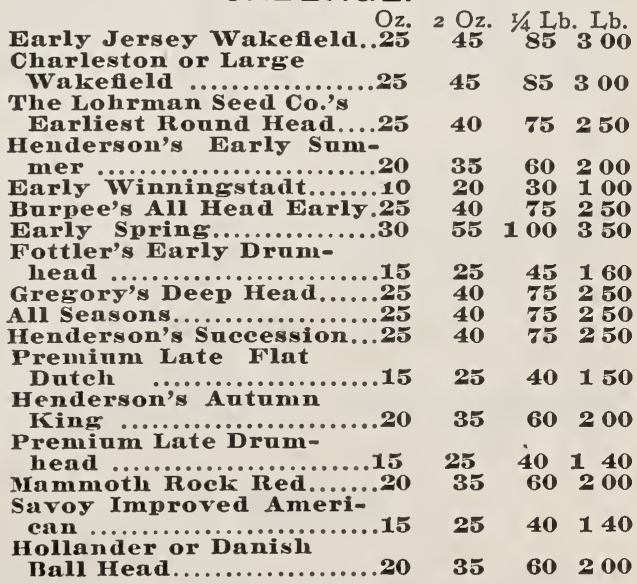




\section{CARROT.}

Chantenay, Oz. $2 \mathrm{Oz} .1 / 4 \mathrm{Lb} . \mathrm{Lb}$. ed .............. Stump RootEarly Scariet Horn............. Guerande, or Oxheart.....10 Half Long scarlet.......... Danver's Half Long..........10 Long Orange Improved...10 Improved Short White....10

Large White Belgian......10

\section{CUCUMBER.}

$\cos$

Early White Spine........10 ${ }^{2} \mathrm{Oz} .15 \mathrm{~L}$ Lb. Lb. Extra Long or Evergreen White Spine...........10 $15 \quad 20 \quad 50$ Improved Long Green.....10 15 15 40 Ear1y Russian...............10 15 15 40 Early Cluster.................10 15 $15 \quad \mathbf{1 5}$ Early Short Green.........10 15 15 Chicago Pickling...........10 $15 \quad 15 \quad 40$

Boston Pickling............10 15 15 40

\section{EGG PLANT.}

$1 / 4 \mathrm{Oz}$. I Oz. $2 \mathrm{Oz}, 1 / 4 \mathrm{Lb}$. Henderson's Early

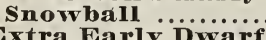
.65 $200 \quad 400 \quad 750$

Erfurt

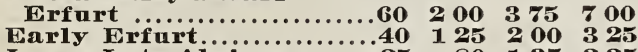
Large Late Aigiers.........25 80 135 225

\section{CELERY.}

Golden Yellow, or Gold-

Oz. $2 \mathrm{Oz} \cdot \mathrm{I} / 4 \mathrm{Lb} \cdot \mathrm{Lb}$.

en Self-Blanching . . . . . 40

Evan's Triumph.............

White Plume.................

Perfection Heartweil................

Golden Heart..............10

Kalamazoo white Solid

Dwarf ...................10

Celery seed for Fiavor-

Celeriac, Large Smooth

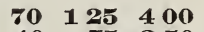

$40 \quad \frac{75}{75} \quad 250$

$\begin{array}{llll}40 & 75 & 2 & 50 \\ 30 & 50 & 1 & 75\end{array}$

2540150

$20 \quad 35125$

$20 \quad 35125$

$10 \quad 10 \quad 30$

Prague

$\ldots 10$

2035125

\section{CORN.}

Mammoth White

Pt. Qt. 2 Qt. 4 Qt. Pk. Bu.

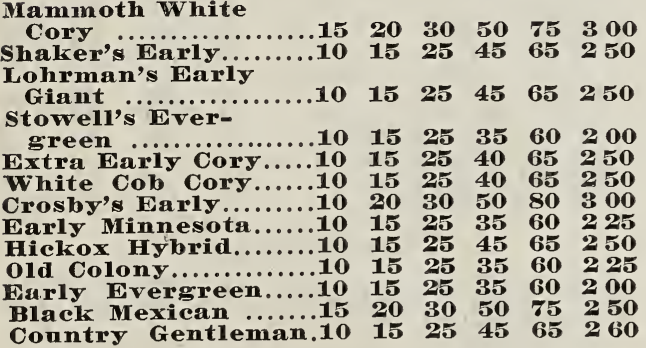

\section{Field Varieties.}

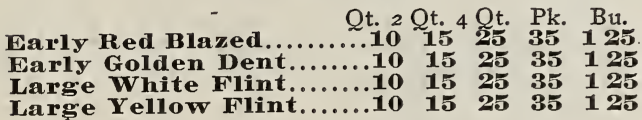

\section{CORN SALAD.}

Large Seeded, Large

Oz. $2 \mathrm{Oz}$. I/4 I, L.

Leaved $10 \quad 15 \quad 15 \quad 40$

\section{CRESS.}

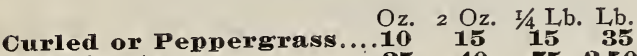
True Water...............25 40 75 250
Improved Large New

Oz. 2 Oz. I/4 L,b. L.b.

York Purple...........25 $45 \quad 80275$

\section{ENDIVE.}

\section{KALE, OR BORECOLE.}

Extra Curled German

Oz. 2 Oz. I/4 L, L. I.

Dwarf Green............ 10 15 $25 \quad 75$ Tall Green Curied Scoteh.10 $15 \quad 20 \cdot 50$

KOHL RABI.

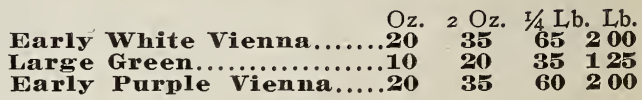

\section{LEEK.}

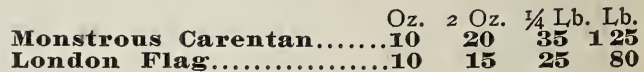

\section{LETTUCE.}

Detroit Market Garden-

Oz. 2 Oz. I/4 Lb. Lb.

er's or Engel's Forcing: 10

Grand Rapids............10

Black Seeded Simpson..............

Mammoth Black Seeded

Butter ...................10

Simpson's Eariy Curled..10

Fariy Curled Silesia.......10

Hanson ....................

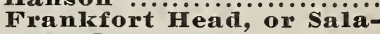

mander ................10

Deacon $\ldots \ldots \ldots \ldots \ldots \ldots \ldots \ldots \ldots \ldots$

Golden Queen................

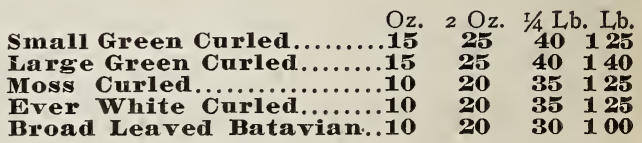

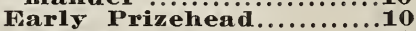


MUSK MELON.

\begin{tabular}{|c|c|c|c|}
\hline & $2 \mathrm{Oz}$. & & \\
\hline $\begin{array}{l}\text { ixtrat wanty hackensach } \\
\text { sage }\end{array}$ & & & \\
\hline $\begin{array}{l}\text { sage } \\
\text { rincess } \ldots \ldots \ldots \ldots \ldots \ldots \ldots \ldots \ldots \ldots \ldots \ldots\end{array}$ & 15 & 20 & 10 \\
\hline Hackensaek ............. & 15 & 1.5 & \\
\hline \multicolumn{4}{|l|}{ Improved Iarage Green } \\
\hline Nutmeg $\ldots \ldots \ldots \ldots \ldots \ldots \ldots$ & 15 & 15 & \\
\hline Enall Green Nutmeg... & 15 & 1.5 & \\
\hline altimore or Acume... & 1: & 15 & \\
\hline Fmerald Gem......... & 15 & 20 & \\
\hline nul Roxe... & 15 & 20 & \\
\hline cotte & 15 & 20 & \\
\hline
\end{tabular}

\section{WATER MELON.}

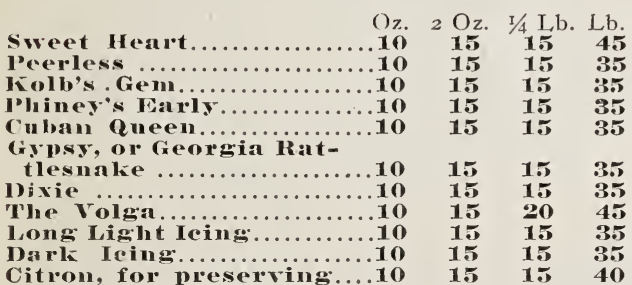

\section{MUSHROOM SPAWN.}

Iinglish in Bricks, 5 lbs., t5e...

PEAS.

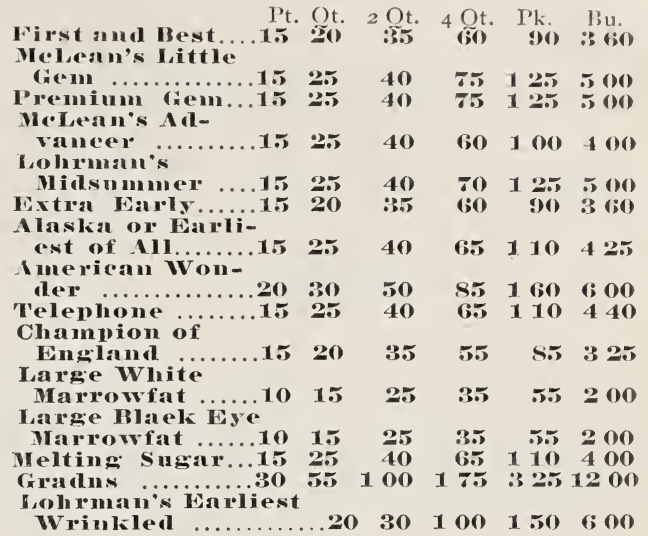

PEPPER.

Red Chili.................20 Long Red Cayenne..........20 Iarge Bell, or Bull Nose..15 Ruby King...............20 sweet Mountain............

$\begin{array}{llll}30 & 50 & 2 & 00 \\ 35 & 60 & 2 & 00 \\ 30 & 50 & 1 & 75 \\ 35 & 65 & 2 & 25 \\ 30 & 50 & 1 & 75\end{array}$

\section{PUMPKIN.}

MUSTARD.

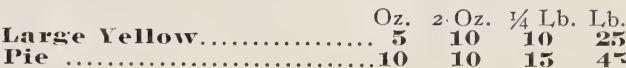

White English............. Oz. ${ }^{2} \mathrm{Oz}, 1 / 4 \mathrm{~L}, \mathrm{~b} . \mathrm{L}, \mathrm{b}$ Sonthern Giant curled.... 5 5 $15 \quad 20 \quad 65$

\section{ONION.}

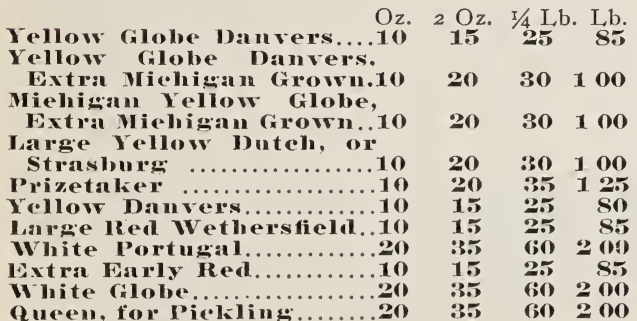

\section{PARSLEY.}

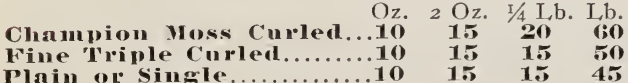

PARSNIP.

$\mathrm{Oz}, 2 \mathrm{Oz}, \mathrm{I} / 4 \mathrm{Lb}, \mathrm{Lb}$

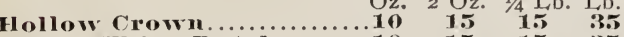
Long White Duteh..........10 15 15

1. ........................

\section{RADISH.}

Early Scarlet Turnip,

Oz. $2 \mathrm{Oz} . \quad \mathrm{r} / 4 \mathrm{Lb} \cdot \mathrm{Ll}$

White Tipped.............

white Tipped. Foreins.10

Wood's Eariy Frame.....10 1501550

Farly Loms Seanlet.

Short 'Top. Improv.ed...10 15 15 50

white Strasbura......... 10 15 20 60

Early Rommd Deen, Seare-

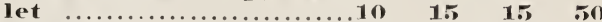

Non Plus uitra............... 10 15 20

Early Searlet Turnip, .... 10 10 $15 \quad 50$

Rooted .................. 10 10 15

Rooted .................. 10 $10 \quad 15 \quad 50$

Early Scarlet Giobe........ 10 15 20 50

rench Breakfast...........10 15 15 45

colden Globe...............10 15 15 40

Long: White Vienna......10 15 1545

Lous. Brishtest Sranlet.

White Tipped............10 15 15 45

Long White Naples........... 15 15 15 40

Seagret China Winter......10

long. White spanisl. 10

Long Gray Ianom.......... 10 15 20 50

I.ong Black Spanish.......10 15 15 50

Round Black Spanish.....10 15 15 50
RAPE.

Dwarf Essex, for Sowing. 
RHUBARB.

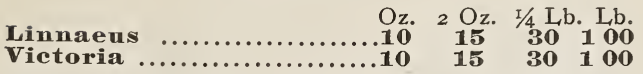

\section{SALSIFY OR VEGETABLE OYSTER}

Mammoth Sandwich IsLarge white...............

\section{SPINACH.}

Long Standing

Lb. Io Lb. $25 \mathrm{Lb}$.

Thick-Leaved

victoria $\ldots \ldots \ldots \ldots \ldots \ldots \ldots \ldots \ldots \ldots 20$

Savoy Leaved..................

Round Sammer................20

Improved Thick-Leaved...20

Prickly Winter Long

Standing:
175375

175375

160350

$175 \quad 375$

$175 \quad 375$

\section{TURNIP--Continued.}

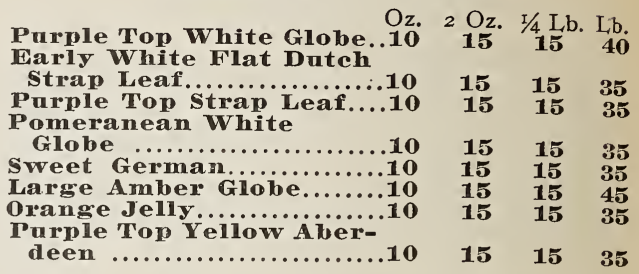

American Purple Top

Yellow, or Long lsiand..10

Improved Purple Top

Yellow .................... Yellow swede.....................

Monarch or Tankard......10

Sweet Russian or White..10

\section{SQUASH.}

Mammoth White Bush $\mathrm{Oz.} 2 \mathrm{Oz} .1 / 4 \mathrm{Lb} . \mathrm{Lb}$. Scallop .................10 $15 \quad 2050$

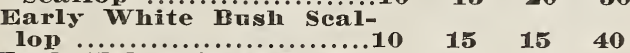

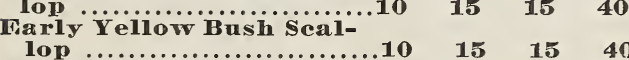

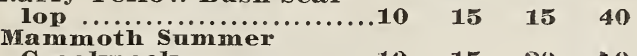
Crookneck .............. 15 $20 \quad 50$ Boston Marrow. $\ldots \ldots \ldots \ldots \ldots \ldots \ldots$
Hubbard $\ldots \ldots \ldots \ldots \ldots \ldots \ldots \ldots \ldots$

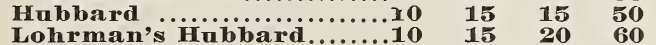
Mammoth Chili............10 $15 \quad 20 \quad 60$

SUNFLOWER.

Large Russian

TOBACCO.

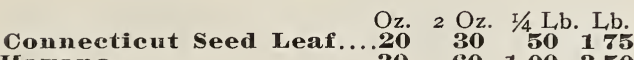
Comnecticut Seed Leaf....20
Havana $\ldots \ldots \ldots \ldots \ldots \ldots \ldots \ldots \ldots \ldots$

TOMATO.

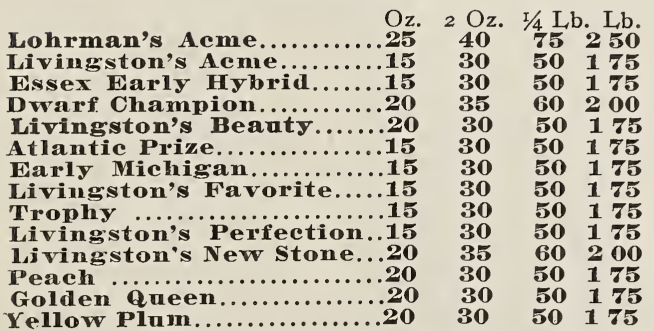

\section{TURNIP.}

White Milan $10.2 \mathrm{Oz} .1 / 4 \mathrm{Lb}$. Lb. Extra Eariy Purple Top

Milan $\ldots \ldots \ldots \ldots \ldots \ldots \ldots \ldots \ldots$ 10

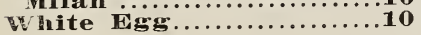

\section{SWEET HERBS.}

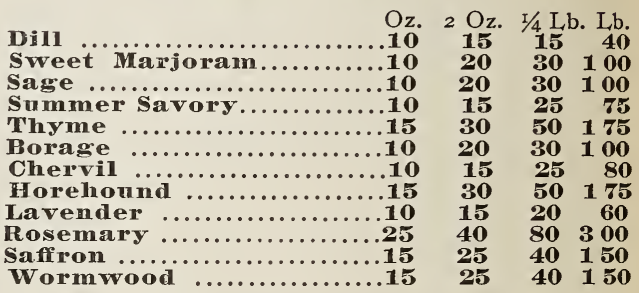

BIRD SEEDS.

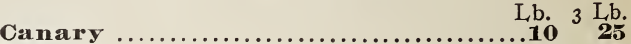

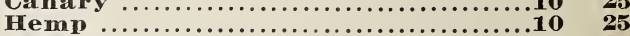

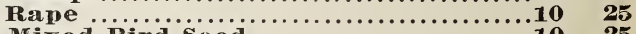

Mixed Bird Seed.....................

Maw

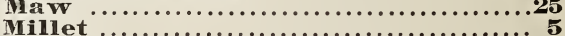

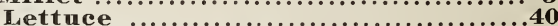

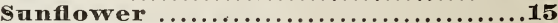

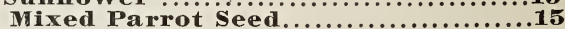

Unhulled Rice..........................

Bird Gravel .............................

\section{CLOVER.}

Per Bu. Market Price.

Vammoth or Large Red $\ldots \ldots \ldots \ldots \ldots \ldots \ldots$. 20c

Lb.

Medium Red or June.........................20e

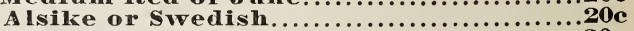

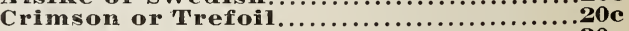

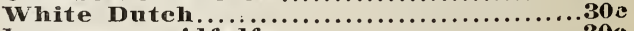

Lucerne or Aifaifa...........................20s

\section{GRASS SEEDS.}

Per Bu. Market Price.

Timothy o..........

(20c

Red Top, Fancy, Cleaned.......................20e Blue Grass, Fancy, Cleaned ..............20e Perennial Rye Grass .....................20c Lohrman's Evergreen Lawn

Grass ..........25e 1b., 5 1b. $\$ 1.00, \$ 4.00$ bu

\section{MISCELLANEOUS.}

Per Bu. Market Price.

Hungarian Grass.

Lb.

ss.......................... 5e

Muckwheat, Silver Huil...................... 5e 


\section{FERTILIZERS AND INSECTICIDES.}

For the Farmer, Gardener and Florist.

\section{CROCKER'S GENERAL CROP PHOS- PHATE.}

Price, I 1b. 5c., ro 1bs. 30c., 50 lbs. $\$ 1.00$, I00 1bs. $\$$ I.50, 250 lbs. barrel $\$ 3.25$, ton $\$ 25$.

\section{LAWN AND GARDEN FERTILIZER.}

A ro-pound package is sufficient to go over an area of I5X20 or 300 square feet. Price, I lb. 5c., ro lbs. $40 \mathrm{c}$, I00 lbs. $\$ 3.00$.

\section{FERTILIZER FOR HOUSE PLANTS.}

It is fine and dry, clean and easy to apply, either Ine soil as a top-dressing, dissolved in water. One teaspoonful is sufficient for dissolved in water.

Price, 1b. 10ci, 3 lbs. 25 c., 25 lbs. $\$ 1.50$, 100 lbs., \$5.00.

\section{NITRATE OF SODA.}

Being extremely soluble it should not be applied until the plants are above ground, when 100 to 500 pounds per acre, mixed with wood ashes or land plaspounds per acre, mixe in applying, are generally used.

Price, I lb. Ioc., 5 lbs. 30 ., IO lbs. 50c., 25 lbs. $\$ 1.25$, 100 lbs. $\$ 4.00$.

\section{BANNER DISSOLVED BONE FLOUR.}

Price, I lb. 10c., 5 lbs. 30c., Io lbs. 50c., 25 lbs. $\$ 1.25$, Ioo lbs. \$4.00.

\section{PARIS GREEN.}

A poisonous, insoluble powder, indispensable on the farm or garden-for preventing the ravages of potato bugs, codling moth, worms, caterpillars, slugs and bugs. Price, I lb. $25 \mathrm{c}$., $1 / 2 \mathrm{lb}$. $15 \mathrm{c}$., $1 / 4 \mathrm{lb}$. Ioc.

\section{PURE WHITE HELEBORE.}

The cheapest and best preparation for destroying rose slugs, currant worms, etc. Price, I lb. 3oc. 1/4 1b. Ioc.

\section{BORDEAUX MIXTURE OR PARIS GREEN COMPOUND.}

\section{Price, I lb. $30 \mathrm{c}$.}

\section{PYRETHRUM OR PERSIAN INSECT POWDER.}

Very destructive to all kinds of insects, such as butterflies and all other insects on cabbage and cauliflower. Price, I lb. 35c., I/2 lb. 20c., $1 / 4$ lb. 15 c.

RUBBER PLANT SPRINKLERS.

$1 / 2$-pint size $60 c, 2-3$ pt. 75 c., I pint $90 c$.

\section{SCOLLAY'S PUTTY BULB.}

$\$ 1.00$ each.

\section{GRAFTING WAX.}

$1 / 2$ lb. 15 c., $1 / 4$ lb. Ioc.

\section{CLOTH HOT BED MATS.}

$76 \times 76$ inches covers two sashes, $\$ 1.50$.

\section{MASTICA FOR GLAZING GREEN - HOUSES AND SASHES.}

Price, quart 40c., $1 / 2$ gal. 70c., gal. \$1.25.

\section{WOODEN POT LABELS.}

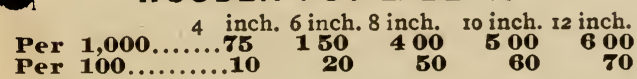

\section{SLUG SHOT.}

A non-poisonous powder and a very popular Insecticide; it requires no further mixing or preparation, easily applied and not injurious or dangerous to animals, the person applying it, or fruits and vegetables treated. Very effectual in destroying potato bugs and beetles, green and black fly, slugs, worms, caterpillars, etc. Price, I lb. roc., 5-lb. package 40c.

\section{NIKOTINE}

Is the most powerful known insecticide, and will be found more economical and convenient than weak tobacco extracts. Price, pint cans $\$ 1.50,5$ cans $\$ 7.00$.

\section{LEMON OIL.}

This well-known insecticide has had for some time a marvelous success in England; perfectly safe and harmless to the tenderest foliage and roots. It effectually destroys mealy bug by syringing or dipping. It also destroys scale, thrip, red spider, black and green fly, caterpillar, American blight, mildew, etc. Dilute with 50 parts water. $1 / 2$ pint $25 \mathrm{c}$., pint $40 \mathrm{c}$., quart $75 \mathrm{c}$., $1 / 2$ gallon $\$ 1.25$, gallon $\$ 2.00$.

\section{WHALE OIL SOAP.}

For insects on plants, and mealy bug on paims and rubber trees, dissolve $1 / 4 \mathrm{lb}$. to a gallon of water. Price, I lb. $20 \mathrm{c}$., $1 / 2 \mathrm{lb}$. Ioc.

\section{FOSTITE.}

A splendid preventative and cure of fungoid diseases, against mildew, black rot, leaf blight, rust, etc., affecting vines, fruits and vegetables. It is a powder, and should be blown on the plants with a powder-bellows or powder-gun, while the foliage is moist, either in the morning or evening, or after syringing.

Price, per $1 \mathrm{~b}$. $15 \mathrm{c}, 5 \mathrm{lbs}$. $50 \mathrm{c}$.

\section{TOBACCO DUST.}

If dusted on while the foliage is moist it destroys rose lice, cabbage and turnip fleas, etc. Spread upon the ground, it keeps off all earth insects, and also acts as an excellent fertilizer. Price, I lb. 5c., 6 lbs. $25 \mathrm{c}$.

\section{WATERS' TREE PRUNERS.}

4 foot 75 c., 6 foot $90 \mathrm{c}$, 8 foot $\$ 1.00$, Io foot $\$ 1.15$, I2 foot, $\$$ I.25.

Pruning Shears..........................75c

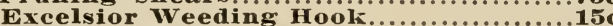

Lang's Hand Weeder......................20c

Steel Garden Trowel............................

UNION FLOWER TUBS.

Cypress, painted green, iron feet.

No. 1, 13 x11 inches.................... \& 75

No. 2,14 x13 inches......................... 100

No. 3, 16 x15 inches........................ 1 $\mathbf{3 5}$

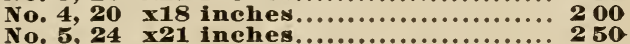

$\$ 2.50$ per 1,000 .

BERRY BASKETS.

$25 \mathrm{C}$ per doz.

FRUIT BASKETS.

$\$ 1.00$ per doz.

BUSHEL BASKETS.

Market price.
JUTE BUNCHING TWINE. 


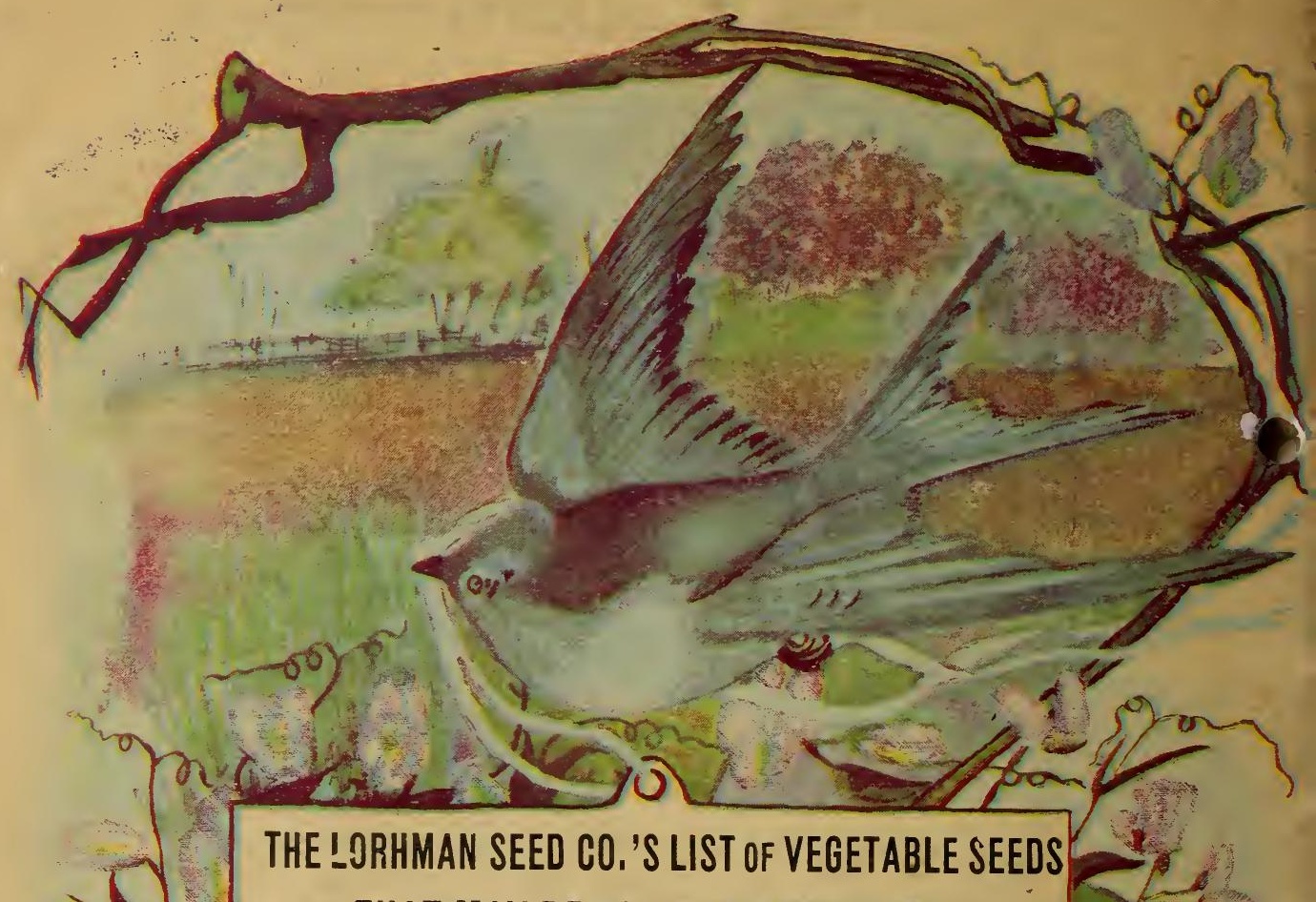

THAT MAY BE SOWN IN EACH MONTH

From February to September in the vicinity of Detroit

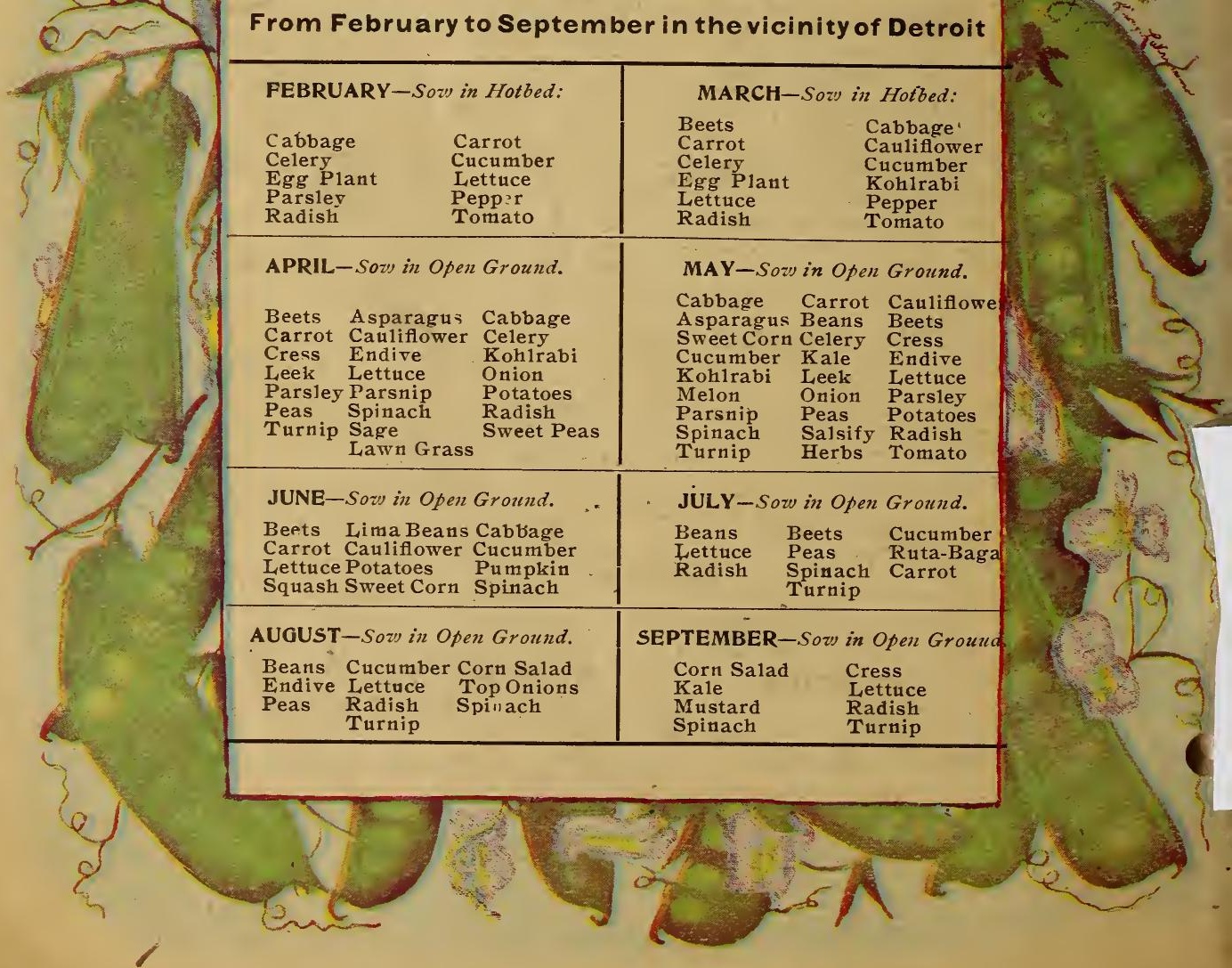

